\title{
Assessment of biochemical recurrence of prostate cancer (Review)
}

\author{
XIAOZENG LIN ${ }^{1-4}$, ANIL KAPOOR ${ }^{2,3,5}$, YAN GU ${ }^{1-4}$, MATHILDA JING CHOW ${ }^{1-4}$, \\ HUI $\mathrm{XU}^{6}$, PIERRE MAJOR ${ }^{7}$ and DAMU TANG ${ }^{1-4}$ \\ ${ }^{1}$ Department of Medicine, McMaster University, Hamilton, ON L8S 4K1; ${ }^{2}$ The Research Institute of St. Joe's Hamilton, \\ ${ }^{3}$ Urological Cancer Center for Research and Innovation (UCCRI), St. Joseph's Hospital; \\ ${ }^{4}$ The Hamilton Center for Kidney Research, St. Joseph's Hospital, Hamilton, ON L8N 4A6; ${ }^{5}$ Department of Surgery, \\ McMaster University, Hamilton, ON L8S 4K1, Canada; ${ }^{6}$ Department of Nephrology, Xiangya Hospital, \\ Central South University, Changsha, Hunan 410008, P.R. China; ${ }^{7}$ Division of Medical Oncology, \\ Department of Oncology, McMaster University, Hamilton, ON L8V 5C2, Canada
}

Received July 5, 2019; Accepted September 24, 2019

DOI: 10.3892/ijo.2019.4893

\begin{abstract}
The assessment of the risk of biochemical recurrence (BCR) is critical in the management of males with prostate cancer (PC). Over the past decades, a comprehensive effort has been focusing on improving risk stratification; a variety of models have been constructed using PC-associated pathological features and molecular alterations occurring at the genome, protein and RNA level. Alterations in RNA expression (lncRNA, miRNA and mRNA) constitute the largest proportion of the biomarkers of BCR. In this article, we systemically review RNA-based BCR biomarkers reported in PubMed according to the PRISMA guidelines. Individual miRNAs, mRNAs, IncRNAs and multigene panels, including the commercially available signatures, Oncotype DX and Prolaris, will be discussed; details related to cohort size, hazard ratio and $95 \%$ confidence intervals will be provided. Mechanistically, these individual biomarkers affect multiple pathways critical to tumorigenesis and progression, including epithelial-mesenchymal transition (EMT), phosphatase and tensin homolog (PTEN), Wnt, growth factor receptor, cell proliferation, immune checkpoints and others. This variety in the mechanisms involved not only validates their associations with BCR, but also highlights the need for the coverage of multiple pathways in order to effectively stratify the risk of BCR. Updates of novel biomarkers and their mechanistic insights are considered, which suggests new avenues to pursue in the prediction of BCR. Additionally, the management of patients with
\end{abstract}

Correspondence to: Professor Damu Tang, The Research Institute of St. Joe's Hamilton, T3310, St. Joseph's Hospital, 50 Charlton Avenue East, Hamilton, ON L8N 4A6, Canada

E-mail:damut@mcmaster.ca

Professor Pierre Major, Division of Medical Oncology, Department of Oncology, McMaster University, 699 Concession Street, Hamilton, ON L8V 5C2, Canada

E-mail:majorp@HHSC.CA

Key words: prostate cancer, biochemical recurrence, biomarkers
BCR and the potential utility of the stratification of the risk of BCR in salvage treatment decision making for these patients are briefly covered. Limitations will also be discussed.

\section{Contents}

1. Introduction

2. Stratification of BCR risk: An update

3. Searching methods for RNA-based BCR biomarkers

4. Gene expression-based biomarkers

5. Management of patients with biochemical recurrence

6. Perspectives

\section{Introduction}

Prostate cancer (PC) is the most commonly diagnosed cancer affecting males in developed countries and a major cause of cancer-related mortality among males (1). The disease is highly heterogeneous and progresses with a large degree of disparity. PC evolves from high-grade prostatic intra-epithelial neoplasia (HGPIN) to local carcinoma; some local tumors will develop into metastatic disease with bone as the preferential site (2). Primary tumors are managed through watchful waiting (active surveillance) and curative therapies: Radical prostatectomy (RP) or radiation therapy (RT) (3-6). The disease may relapse in the form of biochemical recurrence (BCR) with elevations in serum prostate-specific antigen (PSA) levels of $>0.2 \mathrm{ng} / \mathrm{ml}$ following RP and $>2 \mathrm{ng} / \mathrm{ml}$ above the nadir following RT (7). Approximately $30 \%(20-40 \%)$ of patients following RP (8-10) and 30-50\% of males treated with RT will experience BCR $(11,12)$ within 10 years posy-therapy. $\mathrm{BCR}$ represents a major progression and is associated with a significantly increased risk of PC metastasis; 24-34\% of patients with BCR will develop metastasis $(13,14)$. The standard treatment for metastatic PC remains androgen deprivation therapy (ADT); however it is largely a palliative care as metastatic castration-resistant PCs (mCRPCs) commonly develop (15). Although multiple treatment options are 
currently available for mCRPCs, these therapies only marginally prolong the median overall survival (OS) and resistance develops rapidly. This is the major challenge with therapies targeting mCRPCs using docetaxel $(16,17)$ or the second generation anti-androgens (abiraterone and enzalutamide) approved by the FDA in 2011 and $2012(18,19)$. Collectively, with this knowledge of PC development and the current limitations in treating metastasis, the most beneficial management of prostate cancer is through the accurate stratification of patients with $\mathrm{PC}$ with a low risk of BCR progression from those with a high risk. This capacity of BCR risk stratification is of particular relevance to patients with lowand intermediate-risk PCs; low-risk and intermediate-risk PCs are defined by the European Association of Urology (EAU)-European Society for Radiotherapy and Oncology (ESTRO)-International Society of Geriatric Oncology (SIOG) as PSA $<10 \mathrm{ng} / \mathrm{ml}$, Gleason score (GS) <7, cT1-2a, and localized (low risk) and PSA levels of $10-20 \mathrm{ng} / \mathrm{ml}$ or GS 7 or cT2c and localized (intermediate risk) (3).

The current stratification of the risk of BCR in clinical practice remains poor; improvement in this capacity remains a major focus of the research community. Attributing to this massive effort and the involvement of complex networks affecting BCR progression, there are enriched data for BCR risk classification for localized tumors following primary curative treatments, particularly RP. The risk stratification is based on two general aspects of PC: Clinical characteristics and molecular properties or biomarkers. The latter includes alterations in gene expression at both the gene and protein level. Due to the overwhelming amount (search for "prostate cancer AND biomarkers AND biochemical recurrence' in PubMed resulted in 2,500 articles) and the heterogeneity of the data, in this review, we focus on RNA-based biomarkers, which can be effective in nature. We also briefly discuss other types of BCR biomarkers to make this review comprehensive.

\section{Stratification of $B C R$ risk: An update}

Assessment of BCR risk using clinical information. The clinical and tumor characteristics have long been investigated for the estimation of the risk of BCR. By using pre-treatment PSA, the GS, clinical T stage, the percentage of biopsy cores positive for cancer, and age in 1,493 patients treated with RP between 1992 and 2001, the University of California, San Francisco Cancer of the Prostate Risk Assessment (UCSF-CAPRA or CAPRA) was developed in 2005 to appraise the BCR risk; this is a score system with scale of 0-10 and higher scores represent a higher risk of BCR (20). Up to 2017, CAPRA has been validated on BCR risk stratification following RP and RT by 12 investigations carried out in the USA, Germany, Japan, Australia, Korea and Canada; these studies involved a total of 17,457 patients and demonstrated that CAPRA classifies the risk of $\mathrm{BCR}$ with a concordance index (c-index) ranging from 0.67 to 0.81 (20). The status of CAPRA has recently been updated by Brajtbord et al (21); the modified version, CAPRA-S, was subsequently developed by the same group in 2011 and independently validated $(21,22)$. Prior to CAPRA, the D'Amico classification of the risk of BCR was generated by D'Amico et al in 1998 (23). The CAPRA score system seems superior to the D'Amico classification (21).
While approximately $30 \%$ of males undergoing RP will experience BCR within 10 years (8-10), two-thirds of these recurrences occur during the first 2 years (24-26). Early recurrence is associated with a higher risk of metastasis $(27,28)$. To assess early BCR, the Walz nomogram was constructed in 2009 (29), which has recently been updated with 13,797 patients who had undergone radical prostatectomy from Hamburg (2005-2016) and validated using 5,952 males treated with $\mathrm{RP}$ in Vienna (30). The validation using the Vienna dataset revealed the best estimation of $\mathrm{BCR}$ risk by the updated nomogram in comparison to the Walz nomogram, MSKCC nomogram, and CAPRA-S (30). The nomogram estimates BCR risk at 12 and 24 months post-RP based on PSA, GS, pT stage, surgical margin status and lymph node status (30).

Stratification of BCR risk based on protein expression. Abnormalities in the regulation of cell proliferation are typical of cancer (31). Of note, alterations in the expression levels of proteins related to cell cycle regulation have been extensively examined for biomarker values in the classification of the $\mathrm{BCR}$ risk. These proteins include Ki-67, MYC, ETS-related gene (ERG), as well as the tumor suppressors phosphatase and tensin homolog (PTEN) and p53; their biomarker potentials have recently been reviewed $(32,33)$. In brief, $\mathrm{Ki}-67$ is an established cell proliferation marker (34) with increases in its expression being associated with adverse features of PC (33); however, its association with BCR remains uncertain (35).

MYC plays multiple roles in tumorigenesis, which includes the regulation of cancer metabolism $(36,37)$. It is upregulated in PC (38) and contributes to PC progression in part via telomerase overexpression and the loss of PTEN $(39,40)$. While increases in MYC protein expression are associated with higher a GS and T-stage, an association between MYC and BCR remains unclear (33).

The overexpression of ERG in PC results from the fusion of the androgen target gene transmembrane serine protease 2 (TMPRSS2) with ERG (TMPRSS2-ERG) (41). The ERG protein can be detected in PC by immunohistochemistry (IHC) (42). In a systemic review, the overexpression of the ERG protein was shown to be modestly associated with BCR with P-values of 0.04, 0.006, or 0.002 (33).

In a study of 52 males with $\mathrm{PC}$, an association of $\mathrm{p} 53$ expression with BCR was demonstrated $(\mathrm{P}=00097)(43)$, which was corroborated by another small cohort involving 86 patients with PC $(\mathrm{P}<0.01)$ (44). Collectively, IHC-detected p53 protein expression is associated with BCR (33). In a systemic review published in 2018 on the IHC-based detection of BCR (33), the loss of PTEN was found to be associated with BCR in 8 investigations.

Nonetheless, while IHC-detected protein expression can display significant associations with BCR, the associations are modest in most cases and their applications in clinical practice are limited. This is likely attributed to the limited number of proteins that can be simultaneously detected by IHC; the examination of the expression status of a panel of proteins or signatures consisting of multiple factors is critical to effectively stratify the risk of BCR.

Genomic alteration-based biomarkers. While the impact of genomic alterations on PC progression will not be covered 
in this review, it is important to summarize the recent developments related to the impact of germline mutations on PC progression. A family history is a well-recognized risk factor of PC (45); nonetheless, hereditary PCs, which constitute approximately $9 \%$ of all PCs, do not differ from spontaneous PCs based on the 2016 EAU-ESTRO-SIOG guidelines (3). Thus, it was generally accepted that germline mutations do not promote $\mathrm{PC}$ progression and are thus without prognostic value. The exception was first observed with BRCA2 germline mutations that increase the incidence of $\mathrm{PC}$ along with the risk of PC progression $(46,47)$; these mutations drive the evolvement of PC by causing genomic instability (48). In line with this concept, germline mutations in other factors regulating the DNA damage response (DDR) also increase the risk of PC progression, including ATM, CHEK2, BRCA1, RAD51D and PALB2 (49). The observation that BRCA1/2 germline mutations are associated with the risk of PC and PC progression provides additional support for the similarities between PC and breast cancer. This is consistent with a recent study demonstrating that $\mathrm{PC}$ can be grouped into PAM50-based luminal A and luminal B subtypes (50), the well-known subtypes of estrogen receptor-positive breast cancer (51).

It will thus be of interest to investigate the contributions of mutations in BRCA2, ATM, CHEK2, BRCA1, RAD51D and PALB2 in a variety of combinations in the assessment of the risk of BCR. Of note, genomic alterations in 9 DDR pathways involving 17 gene sets are able to classify the risk of BCR [population size, $\mathrm{n}=545$; hazard ratio (HR), 1.89; $95 \%$ confidence interval (95\% CI), 1.44-2.48; P=5.01e-6] (52).

Among the PC-associated genomic abnormalities, the TMPRSS2-ERG fusion is the most common event; it occurs in approximately $50 \%$ of Caucasian Americans, $31 \%$ of African Americans (53) and $18.5 \%$ of Asians (54). While the fusion gene is modestly associated with T-stage [T3-T4 vs. T1-T2; odds ratio (OR), 1.4; 95\% CI, 1.33-1.48] and metastasis (M1 vs. M0; OR, 1.35; 95\% CI, 1.02-1.78), TMPRSS2-ERG is not associated with BCR (55). Collectively, the current evidence does not support genomic alterations being robust predictors in the assessment of the risk of BCR.

\section{Searching methods for RNA-based BCR biomarkers}

In accordance with the PRISMA guidelines (56,57), we performed a systemic literature search through the PubMed database using the terms 'prostate cancer' AND 'biomarker' AND 'gene expression' AND 'biochemical recurrence'. A total of 258 manuscripts were retrieved. We examined all abstracts and eliminated those i) with population sizes (tumor + non-tumor tissues) $<100$ cases; ii) that focus on DNA methylation and epigenetic regulation without a clear examination of gene expression; iii) that primarily use the immunohistochemistry approach; iv) those yielding values of $P \geq 0.05$. We thus selected and discussed 50 articles in this review (Fig. 1). These papers cover two general aspects of RNA-based biomarkers: mRNAs and microRNAs (miRNAs or miRs).

In light of the important function of long non-coding RNAs (lncRNAs) in preventing miRNA-mediated mRNA degradation via competing or sponging, we also discuss the association of lncRNAs with BCR.

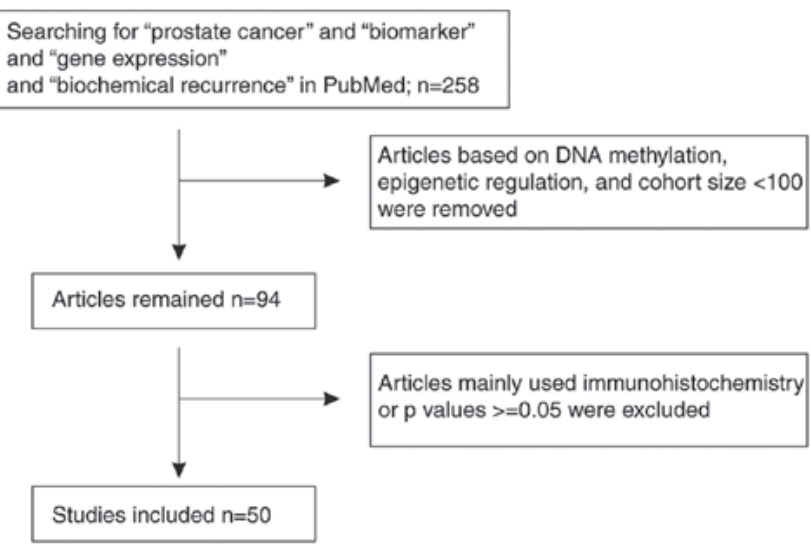

Figure 1. Systemic literature searching conditions and selection of articles for the review.

\section{Gene expression-based biomarkers}

miRNA-based biomarkers for the stratification of BCR risk. Alterations in individual miRNAs have been observed to be associated with BCR (Table I). In a total of 585 patients consisting of 388 non-recurrences and 197 recurrences, using the median expression level as the cut-off point, PCs with high levels of miR-301a were found to be at risk of BCR progression with an adjusted HR of $1.42(\mathrm{P}=0.002)(58)$. PCs positive for miR-21, defined by its median expression level, were also found to be associated with a rapid kinetic of BCR (59). Upregulations in the levels of miR-128 (60) and 130b (61) have also been found to be associated with a reduction in BCR-free survival (Table I). Downregulations in the expression of miR-30C (62), miR-145 (63), miR-195 (64) and miR-16 (64) facilitate BCR development (Table I).

These miRNAs affect BCR by regulating different pathways (Fig. 2), a concept that is consistent with the involvement of complex pathways in BCR occurrence. miR-301a likely promotes the recurrence of $\mathrm{PC}$ at least in part via the induction of epithelial-mesenchymal transition (EMT), evidence by the downregulation of E-cadherin in LNCaP cells overexpressing miR-301a (58). EMT is a major mechanism contributing to cancer stem cells (CSCs) (65). Cumulative evidence supports an essential role of CSCs in cancer progression, including PC (66). miR-21 reduces PTEN expression with the concurrent upregulation of PI3K and AKT, suggesting its role in inhibiting PTEN function in PC (67). miR-30c downregulates EMT by inhibiting the Snail-TGF- $\beta 1$ connection in other settings (68) and is reduced in PC (69); miR-145 is a tumor suppressor (70) and is downregulated in PC (71,72). Both miR-195 and miR-16 inhibit programmed death-1 ligand 1 (PD-L1) expression, and thus downregulate PD-L1-mediated actions of immune checkpoints (64); reductions of either likely promote BCR.

Importantly, individual miRNAs commonly regulate multiple targets (73). This information may enhance the biomarker values of miRNAs, as BCR is certainly regulated by complex networks; however, it may also attenuate their biomarker potential if individual targets have different effects on BCR. For instance, by a functional screening of 1,129 miRNAs for their effects on the proliferation, viability and the apoptosis of 5 PC cell lines, miR-130b was among the 
Table I. Associations of individual miRNAs with BCR defined by univariate Cox analysis.

\begin{tabular}{|c|c|c|c|c|c|}
\hline Identity & Cohort size (n) & Follow-up & HR (95\% CI) & P-value & (Refs.) \\
\hline $\operatorname{miR}-301 a^{b}$ & 585 & $180 \mathrm{M}$ & $1.42(1.06-1.90)$ & 0.002 & $(58)$ \\
\hline $\operatorname{miR}-21^{b}$ & 169 & $84 \mathrm{M}$ & NA & $<0.001$ & (59) \\
\hline $\operatorname{miR}-128^{c}$ & 128 & $100 \mathrm{M}$ & $3.96(1.02-8.12)$ & $<0.001$ & $(60)$ \\
\hline $\operatorname{miR}-30 c^{c}$ & 103 & $125 \mathrm{M}$ & $0.31(0.19-0.51)$ & $<0.001$ & (62) \\
\hline $\operatorname{miR}-145^{c}$ & 137 & $72 \mathrm{M}$ & $3.21(1.07-9.62)^{\mathrm{a}}$ & 0.007 & (63) \\
\hline $\operatorname{miR}-195^{c}$ & 131 & $150 \mathrm{M}$ & NA & 0.0092 & (64) \\
\hline $\operatorname{miR}-16^{\mathrm{c}}$ & 131 & $150 \mathrm{M}$ & NA & 0.0031 & (64) \\
\hline $\operatorname{miR}-130 b^{c}$ & 188 & $120 \mathrm{M}$ & NA & 0.004 & (61) \\
\hline
\end{tabular}

${ }^{\text {a} H a z a r d ~ r a t i o ~(H R) ~ w a s ~ d e t e r m i n e d ~ o n ~ m i-R 145 ~ d o w n r e g u l a t i o n s ; ~}{ }^{b}$ increases and ${ }^{\mathrm{c}}$ decreases in expression associated with BCR. $\mathrm{M}$, months; CI, confidence interval; NA, not available; BCR, biochemical recurrence.

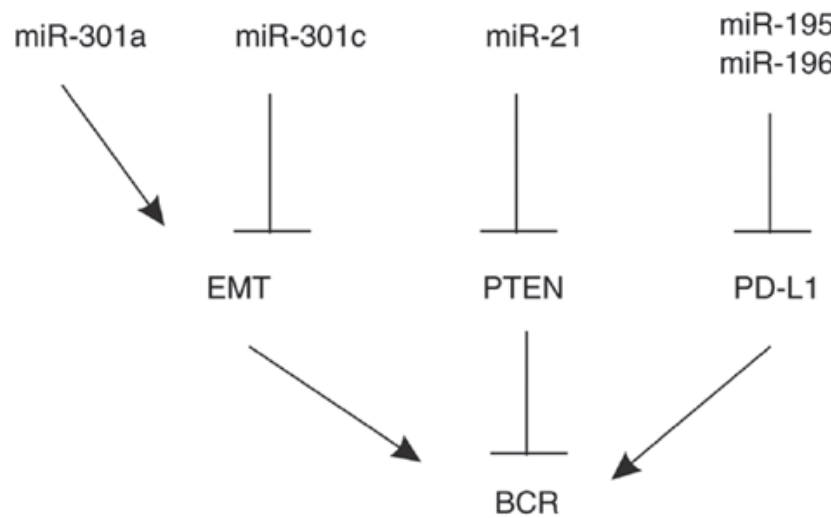

Figure 2. MicroRNAs affecting BCR through multiple pathways. BCR, biochemical recurrence; EMT, epithelial-mesenchymal transition; PTEN, phosphatase and tensin homolog; PD-L1, programmed death-1 ligand 1.

14 miRNAs selected from the screen; it affects cell proliferation and is the only miRNA exhibiting an association with a reduction in BCR-free survival (Table I) (61). The number of predicted targets for miR-130b is approaching 600 with approximately one-third being upregulated (61). Among the two most frequently affected genes, GLYATL1 was upregulated and PARVA was downregulated; and only decreases in PARVA expression are associated with the occurrence of BCR, which is consistent with the effect of miR-130b on BCR (61). The numerous downstream effectors of these miRNAs may contribute to their ineffectiveness in the classification of the risk of BCR (Table I); this limitation should be considered when using miRNAs for the assessment of the risk of BCR.

Single mRNA-based biomarkers. Progression to BCR is regulated by multiple pathways, including Wnt signaling (74), cell proliferation regulations (75), the inhibition of immune checkpoints $(76,77)$ and others. The secreted frizzled-related protein 4 (SFRP4) regulates Wnt signaling and displays oncogenic properties in PC (78). In a study of 9 cohorts, elevations in SFRP4 mRNA expression were found to be a risk factor for BCR in 7 cohorts of 1,404 patients with the HR ranging from 1.3-2.18 (Table II); however in 2 cohorts (patients, $n=374$ ),
SFRP4 was not found to be significantly associated with BCR (79). In another investigation of 536 males with PC, the increase in SFRP4 expression was found to be associated with BCR (HR, 1.35; P=0.009) (80).

The AXIN2 protein plays a role in canonical Wnt signaling (81) and is expressed in tissue stem cells and CSCs (82-84). The single nucleotide polymorphism (guanine/adenine) rs2240308 is associated with a decrease in the risk of $\mathrm{PC}(\mathrm{OR}, 0.377$; 95\% CI, 0.206-0.688; $\mathrm{P}=0.001)(85)$. Of note, the downregulation of AXIN2 mRNA expression has been found to be a risk factor of BCR (Table II) (86).

An increase in platelet-derived growth factor receptor (PDGFR)- $\beta$ expression in the stroma significantly enhances BCR (Table II) (87). An elevated stromal PDGFR- $\beta$ expression has been shown to be associated with a poor prognosis in both breast and prostate cancer (88).

The downregulation of metallothionein 1E (MT1E) is a risk factor for BCR in association with promoter methylation (89). MT1E belongs to the metallothionein (MT) family consisting of cysteine-rich small proteins that regulate metal homeostasis (90). In addition to PC, MT1E is also downregulated in endometrial carcinoma (91), intrahepatic cholangiocarcinoma (92), melanoma (93), non-small cell lung cancer (94), papillary thyroid carcinoma (95) and renal cell carcinoma (96); in the majority of these cancer types, the reductions are associated with hypermethylation (90). However, the upregulation of MT1E has been reported in estrogen receptor-negative breast cancer (97) and it also facilitates glioma progression $(98,99)$.

Increases in KLK15 mRNA expression predict BCR (Table II) (100). KLK15 is a member of kallikrein-related peptidases with KLK3 being the most well-known PSA. KLK15 has been reported to exhibit biomarker value in ovarian, breast, prostate and testicular cancer (101).

An elevation in neuropilin-1 (NRP1) mRNA expression is associated with BCR following RT (Table II) (102). This transmembrane glycoprotein can activate PDGFR- $\beta$ (103) and contributes to the stemness of breast CSCs via the activation of Wnt signaling (104). NRP1 has been reported to be upregulated in PC (105) and may contribute to BCR in part through the regulation of endothelial cell functions (106). 
Table II. Associations of individual mRNAs with BCR defined by Cox analysis.

\begin{tabular}{lclccc}
\hline mRNAs & Patients $(\mathrm{n})$ & \multicolumn{1}{c}{ Pathways } & HR $(95 \% \mathrm{CI})$ & P-value & (Refs.) \\
\hline SFRP4 $^{\mathrm{a}}$ & $1,404+536$ & Wnt & $1.3-2.18^{\mathrm{c}}$ & $0.022-1.88 \mathrm{e}-7^{\mathrm{c}}$ & $(79,80)$ \\
AXIN2 $^{\mathrm{b}}$ & 951 & Wnt & $0.13(0.02-0.67)^{\mathrm{d}}$ & 0.02 & $(86)$ \\
PDGFR- $^{\mathrm{a}}$ & 535 & Proliferation & $1.58(1.18-2.13)$ & 0.002 & $(87)$ \\
MT1E $^{\mathrm{b}}$ & 108 & Metal homeostasis & NA & $<0.001$ & $(89)$ \\
KLK15 $^{\mathrm{a}}$ & 150 & Serine protease & $3.44(1.35-8.75)$ & 0.01 & $(100)$ \\
NRP1 $^{\mathrm{a}}$ & 130 & Androgen signaling & NA & 0.0002 & $(102)$ \\
SAMD5 $^{\mathrm{a}}$ & 345 & NA & $2.18(1.20-3.97)$ & 0.011 & $(107)$ \\
SMAD4 $^{\mathrm{b}}$ & 140 & TGF- $\beta$ & $4.61(2.15-9.89)$ & $<0.001$ & $(113)$ \\
PLAGL2 $^{\mathrm{a}}$ & 104 & Wnt & $3.97(1.21-13.00)$ & 0.023 & $(114)$ \\
PD-L2 $^{\mathrm{a}}$ & 9,393 & Immune checkpoint & $1.17(1.03-1.33)$ & 0.01 & $(119)$ \\
RNase $^{\mathrm{b}}$ & 111 & RNA metabolism & $0.85(0.77-0.91)$ & 0.002 & $(120)$ \\
GLTSCR1 $^{\mathrm{a}}$ & 499 & Chromatin remodeling & $2.28(1.28-4.05)$ & 0.005 & $(122)$ \\
BChE $^{\mathrm{a}}$ & 385 & Hydrolyzing ghrelin and bioactive esters & NA & $0.008-0.04^{\mathrm{c}}$ & $(125)$ \\
\hline
\end{tabular}

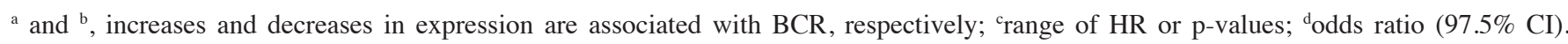
HR, hazard ratio; NA, not available; BCR, biochemical recurrence.

Increases in sterile alpha motif domain containing 5 (SAMD5) mRNA expression display biomarker values in predicting BCR (Table II) (107). SAMD5 facilitates small cell lung cancer cell proliferation (108), is upregulated in cholangiocarcinoma (109) and is associated with the response to chemotherapy in rectal cancer (110). SAMD5 facilitates the Eph receptor tyrosine kinase signaling (111), suggesting a mechanism mediating SAMD5 oncogenic potential and its association with BCR.

Consistent with SMAD4 as a tumor suppressor in the inhibition of PTEN inactivation-induced PC progression (112), a reduction in SMAD4 mRNA expression enhances the risk of BCR (113).

The downregulation of pleomorphic adenoma gene like-2 (PLAGL2) mRNA expression is a risk factor of BCR (114). PLAGL2 is a transcription factor that has been shown to activate $\mathrm{Wnt} / \beta$-catenin signaling through unidentified mechanisms in colorectal cancer (115) and gliomas (116). PLAGL2 also contributes to hematopoietic tumorigenesis $(117,118)$; however, its involvement in PC has not yet been fully investigated.

In an analysis of 7,826 prospectively collected RP tissues and 1,567 retrospectively obtained samples, while PD-L1 did not exhibit prognostic values, an increase in PD-L2 expression was associated with a decrease in BCR-free survival (Table II), distant-free metastasis survival (HR, 1.25; 95\% CI, 1.05-1.49; $\mathrm{P}=0.01$ ) and $\mathrm{PC}$-specific survival (HR, $1.45 ; 95 \% \mathrm{CI}$, 1.13-1.86; $\mathrm{P}=0.003$ ) (119). These observations are in line with the actions of the immune checkpoint in the downregulation of immunoresponses to cancers. Nonetheless, these associations are not particularly robust.

RNase khas been shown to be downregulated in PC $(\mathrm{n}=111)$ in comparison to benign prostatic hyperplasia (BPH); the downregulation was associated with BCR (Table II) (120). The contributions of RNase $\mathrm{k}$ to tumorigenesis in general remain unclear (121).
An upregulation of glioma tumor suppressor candidate region gene 1 (GLTSCR1) in PC vs. normal prostate tissues has been reported; the upregulation is a risk factor of BCR (122). Evidence suggests an oncogenic role of GLTSCR1 in oligodendrogliomas (123). Although the functionality of GLTSCR1 in tumorigenesis remains unclear, recent evidence indicates its role in chromatin remodeling (124), implying GLTSCR1 may contribute to $\mathrm{BCR}$ progression via epigenetic regulations.

Butyrylcholinesterase (BChE) was recently reported to display a biphasic alteration in PCs in both the MSKCC $(n=140)$ and TCGA $(n=245)$ databases; elevations in BChE mRNA expression have been shown to be associated with BCR in both cohorts $(\mathrm{P}=0.008$ for MSKCC and $\mathrm{P}=0.04$ for TCGA) (Table II) (125). BChE has been shown to hydrolyze butyrylcholine (126), succinylcholine (127) and ghrelin (the hunger hormone) (128-131), and thus may play a role in PC metabolism.

Collectively, the above individual mRNAs stratify BCR risk through different pathways, including the Wnt pathway, growth factor receptor-mediated cell proliferation, androgen signaling, cytokines, immune checkpoints, RNA metabolism and others (Table II). While this is in accordance with the complex nature of BCR progression, it also reveals the challenge of using individual mRNA to effectively predict BCR risk and the calls for developing multigene sets or signatures for assessing BCR development.

Multigene sets of mRNAs in assessing BCR risk. To enhance the accuracy of predicting BCR risk, there have been numerous efforts made towards the construction of multigene panels; the rapid accumulation of cancer genomic data owing to technology advances in DNA sequencing [next generation sequencing (NGS)] greatly facilitates this exploration. Among these multigene panels, only three are commercially available to assist patient management. The 22-gene Decipher is intended to predict metastasis following RP (132-134); both 
the 17-gene Oncotype DX [Genomic Prostate Score (GPS)] and the 31-gene Prolaris [Cell Cycle Progression (CCP)] stratify patients at risk of $\mathrm{PC}$ recurrence at the time of diagnosis (135-139) and following RP $(140,141)$. Herein, we briefly review Oncotype DX GPS and CCP and discuss other multigene panels regarding their potentials and limitations.

Oncotype DX prostate cancer assay (GPS) and prolaris $(C C P)$. Oncotype DX Prostate Cancer Assay was developed by Genomic Health Inc. as an assay in the Oncotype DX assays for multiple cancer types. Oncotype DX GPS is a RT-PCR assay on 12 cancer-related and 5 reference genes (ARF1, ATP5E, CLTC, GSP1 and $P G K 1$ ) using biopsy tissues (135); the 12 genes function in 4 aspects of $\mathrm{PC}$ tumorigenesis, including a stromal process (BGN,COL1A1 and SFRP4), cellular organization pathway (FLNC, GSN, TPM2 and GSTM2), androgen signaling (FAM13C, KLK2, AZGP1 and SRD5A2) and cell proliferation regulation (TPX2) (135). They were selected from 732 candidate genes, which were narrowed down from an initial set of 1,082 nominating candidates, through a variety of processes involving multiple data-mining models (136). PGS in the scale of 0-100 can be calculated based on the normalized expressions of 12 cancer-related genes with increased scores indicating elevations in BCR risk (136). In patients with low-risk (GS 6) or intermediate-risk (GS 3+4) PC, GPS predicts BCR (n=382; HR, 2.73; 95\% CI, 1.84-3.96; $\mathrm{P}<0.001)$ (140). In a recent validation study, GPS classified PCs at risk of BCR ( $n=259$; HR, 2.5; $95 \%$ CI, 1.28-3.03; $\mathrm{P}=0.002$ ) (142). Furthermore, in a late multiple institutional investigation involving 1,200 males with very low-, low- and intermediate-risk PCs, GPS predicted adverse pathological features of PC (143). Although GPS has been independently validated for the better management of patients with low- and intermediate-risk PC, the system could be improved. For instance, GPS does not significantly predict BCR in patients who are $<56$ years old $(n=100)(140)$; the cellular organization group score, 3 of 4 component genes of this group, and the proliferation group score do not individually predict BCR risk (140), which reduces the biomarker value of GPS. Although the 12 cancer-related genes were selected via a thorough and complex process from 732 candidates (136), it is of concern whether too many manipulations may not produce the best model.

Genes regulating CCP possess prognostic potential in assessing cancer progression (144). Of note, a panel of $31 \mathrm{CCP}$ genes has been selected from 126 cell cycle progression genes, which together with 15 housekeeping genes form the Prolaris (CCP) multigene panel (Myriad Genetics Int.) (137). Prolaris is a RT-PCR based assay on formalin-fixed paraffin-embedded tumor tissues and provides risk assessment of BCR progression (137). The risk stratification has been validated (Table III) (141,145-147). Evidence also indicates its utilization in the risk stratification of PC fatality $(n=349 ; \mathrm{HR}, 2.02 ; 95 \% \mathrm{CI}$, 1.62-2.53; $\mathrm{P}<1 \mathrm{e}-9)$ (148). However, variations in the effectiveness of BCR risk stratification of some studies were apparent; for instance, in the study involving 236 patients (Table III), HR was modest and the lower HR in the $95 \%$ CI range was marginal (Table III). Additionally, it remains uncertain whether the Prolaris CCP test will have an impact on PC death and is unlikely to facilitate treatment decision; the cost of test is also high (149). Nonetheless, both Oncotype DX GPS and Prolaris CCP are commercially available to assess BCR risk.
Other multigene signatures with biomarker values in BCR risk assessment. Even with the construction of Oncotype DX GPS and Prolaris CCP multigene panels, there is clearly a need to improve the assessment of BCR. To fulfill this need, there are numerous additional multigene sets reported (Table IV), including a 6-differentially expressed gene (DEG) panel (150), an 8-gene panel with its risk scores predicting BCR at $\mathrm{P}=5 \mathrm{e}-7$ (151), and a 10-gene panel HDDA10 (152) (Table IV).

Hypoxia is well known to promote PC progression via multiple pathways, including inflammation and notch signaling $(153,154)$. To examine the prognostic values of hypoxia-induced events in PC progression, Yang et al derived a 28-gene hypoxia-related prognostic signature from 848 differentially expressed genes that were identified in human PC cell lines cultured under hypoxic and normoxic conditions (155). The signature modestly predicts BCR in RP patients receiving post-operative radiotherapy (155) (Table IV).

Instead of focusing on a particular pathway, a 15-gene signature has recently been formulated from the MUC1 network (SigMuc1NW) (156); the signature was validated in the MSKCC dataset. SigMuc1NW stratifies the BCR risk in the MSKCC dataset at P-value 3.11e-15 (156). MUC1 is the most intensively investigated tumor-associated antigen (157-159) and is an attractive target for developing immunotherapies for multiple tumor types (160). MUC1 upregulation is weakly associated with BCR occurrence and PC mortality $(161,162)$. The biomarker potential of MUC1 alterations in the classification of BCR risk was significantly enhanced in a 9-gene genomic signature (163). The 15-gene SigMuc1NW was derived using the 9-gene signature-associated DEGs (156). SigMuc1NW is an independent risk factor of BCR (HR, 2.44; 95\% CI, 1.53-3.87; $\mathrm{P}=1.62 \mathrm{e}-4)$ after adjusting for age at diagnosis, GS, surgical margin and tumor stage (156). Among its 15 component genes, 8 (SLCO2A1, SUPV3L1, TATDN2, MGAT4B, VAV2, SLC25A33, ASNS and OIP5) individually predict BCR after adjusting the clinical features (156). Another attractive feature of SigMuc1NW lies in its novelty; among the 15 component genes, 11 have not been reported in PC particularly and/or tumorigenesis in general (156).

The inclusion of Opa interacting protein 5 (OIP5) in SigMuc1NW is intriguing; it is a cancer-testis antigen and thus a tumor-associated antigen (TAA) detected in other cancer types (164). OIP5 is likely a novel PC-associated TAA. More appealingly, recent developments revealed an essential role of OIP5 in chromosome segregation during cell cycle progression. OIP5 is also known as Miss18 $\beta$, that plays a critical role in centromere formation during the G1 phase $(165,166)$. In accordance with this knowledge, OIP5 is an independent risk factor for BCR (HR, 1.94; 95\% CI, 1.20-3.12; P=0.00638) after adjusting for age at diagnosis, GS, surgical margin and tumor stage (156); OIP5 promotes bladder cancer metastasis and chemoresistance (167), glioblastoma metastasis (168), it displays a biomarker potential in clear cell renal cell carcinoma (169), and it is upregulated in colorectal and breast cancer $(170,171)$.

In line with the concept of the involvement of multiple pathways in BCR progression and the robustness of SigMuc1NW in the classification of BCR risk (Table IV) (156), our recent analysis revealed the signature's 15 component genes (Table IV) 
Table III. Prolaris predicts BCR risk.

\begin{tabular}{lccc}
\hline Cohort $(\mathrm{n})$ & HR $(95 \% \mathrm{CI}), \mathrm{P}_{\text {-value }}^{\mathrm{a}}$ & HR $(95 \%$ CI $)$, P-value & $($ Refs. $)$ \\
\hline 366 & $1.89(1.54-2.31), 5.6 \mathrm{e}-9$ & $1.77(1.4-2.22), 4.3 \mathrm{e}-6$ & $(137)$ \\
413 & $2.1(1.6-2.9),<0.001$ & $2.0(1.4-2.8),<0.001$ & $(141)$ \\
141 & $2.55(1.43-4.55), 0.0017$ & $2.11(1.05-4.25), 0.034$ \\
582 & $1.6(1.35-1.90), 2.4 \mathrm{e}-7$ & $1.47(1.23-1.76), 4.7 \mathrm{e}-5$ & $(145)$ \\
236 & $1.46(1.06-2.10), 0.002$ & $1.41(1.02-1.96), 0.039$ \\
\hline
\end{tabular}

${ }^{a}$ Univariate analysis; ${ }^{\mathrm{b}}$ multivariate analysis. HR, hazard ratio; BCR, biochemical recurrence.

Table IV. Multigene sets with the potential to assess BCR risk.

\begin{tabular}{|c|c|c|c|c|}
\hline Gene set & Components & Cohort (n) & HR (95\% CI), P-value & (Refs.) \\
\hline $6 \mathrm{DEG}$ & $\begin{array}{l}\text { SMIM22, NINL, NRG2, } \\
\text { TOP2A, REPS2, TPCN2 }\end{array}$ & 358 & 3.815 (2.1-6.932), $\mathrm{P}<0.001$ & $(150)$ \\
\hline 8 genes & $\begin{array}{l}\text { CHST1, ACOX1, CTBS, } \\
\text { CNPNAT1, NAGLU, LPIN3, } \\
\text { ASRGL1, HMGCS2 }\end{array}$ & 308 & $\mathrm{NA}, \mathrm{P}=5 \mathrm{e}-7$ & (151) \\
\hline HDDA10 & $\begin{array}{l}\text { FRZB, LEF1, SDCBP, WNT2, } \\
\text { ING3, ANK3, MEIS2, ANXA4, } \\
\text { PLA2G7, CHD5 }\end{array}$ & 758 & $2.08(1.2-3.6), P=0.008$ & $(152)$ \\
\hline $\begin{array}{l}\text { 28-Gene } \\
\text { hypoxia-related } \\
\text { prognostic signature }\end{array}$ & $\begin{array}{l}\text { ADAMTS4, ATF3, BHLHE40, } \\
\text { BTG2, CSRNP1, CYR61, } \\
\text { EGR1, EGR2, EGR3, FOSB, } \\
\text { FOSL2, GEM, JUNB, KLF10, } \\
\text { KLF6, LIF, MCL1, NR4A3, } \\
\text { PPP1R15A, RHOB, SELE, SIK1, } \\
\text { SLC2A14, SLC2A3, SOCS3, } \\
\text { THBS1, TIPARP, ZFP36 }\end{array}$ & 130 & $2.81(1.33-6.0), \mathrm{P}=0.007$ & $(155)$ \\
\hline SigMuc1NW & $\begin{array}{l}\text { SLCO2A1, CGNL1, SUPV3L1, } \\
\text { TATDN2, MGAT4B, VAV2, } \\
\text { SLC25A33, MCCC1, ASNS, } \\
\text { CASKIN1, DNMT3B, AURKA, } \\
\text { OIP5, CTHRC1, GOLGA7B }\end{array}$ & 490 & $4.16(2.74-6.36), P=5.54 \mathrm{e}-11$ & $(156)$ \\
\hline
\end{tabular}

HR, hazard ratio; BCR, biochemical recurrence.

being grouped into 5 clusters using Kendall, Spearman's and Pearson correlation (Fig. 3). Collectively, evidence supports SigMuc1NW as a novel and robust multigene signature. Nonetheless, its biomarker value has not been independently tested.

Evaluation of BCR risk using lncRNAs. While the mechanisms underlying the lncRNA-mediated regulation of gene expression remain incompletely understood, they are likely regulated through complex actions at the genome (chromatin remodeling), mRNA and protein levels (172). Of these, its function as miRNA sponges is emerging as a prevalent mechanism $(172,173)$. In this regard, this section reviews the current evidence for lncRNAs as classifiers of BCR risk. For a comprehensive review, we first searched PubMed for 'IncRNA' AND 'prostate cancer' AND 'biochemical recurrence', and retrieved 15 articles. With exclusion of one non-accessible publication and three articles in which the association of lncRNAs with BCR was not clear, 11 manuscripts are included (179) and Tables V and VI.

A set of PC-associated lncRNAs $(n=54)$ have been recently reviewed (174); they are involved in $\mathrm{PC}$ initiation and progression. A well-known lncRNA in PC is PCA3. It is robustly upregulated in PC compared to prostate tissues (175) and is the second biomarker used in the clinic for PC detection, particularly in decision making for repeat biopsies (176-178). Several lncRNAs have been demonstrated to predict the risk of BCR either individually or in a panel; this has been reviewed in 2017 by Ma et al (179) and Wu et al (180). In this section, we provide an update of the topic with current research. 


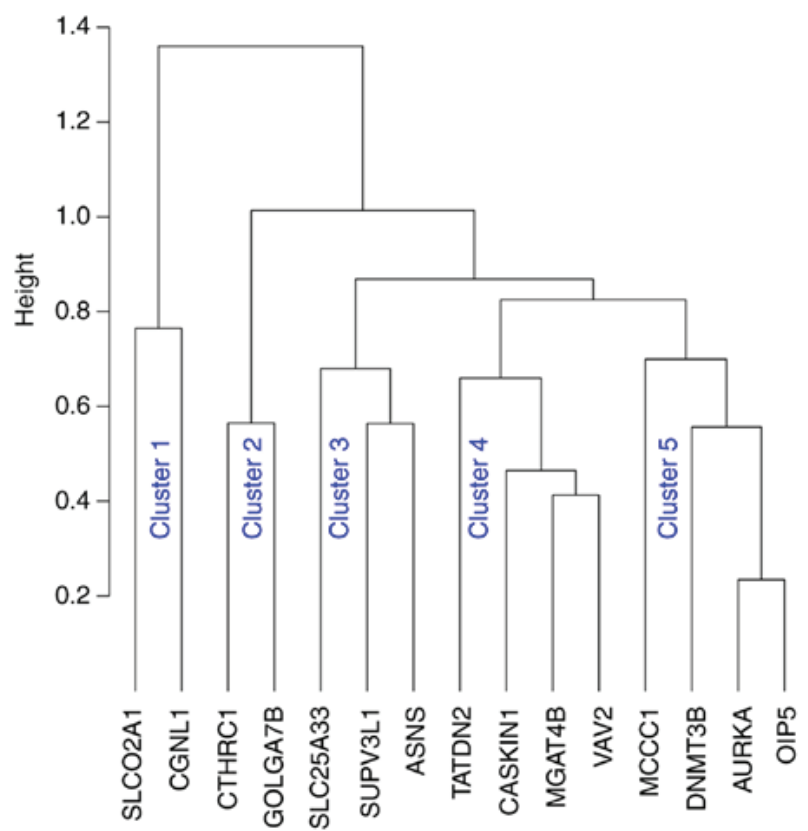

Figure 3. Hierarchical clustering of SigMuc1NW. The RNA sequencing data of the 15 component genes of SigMuc1NW (Table IV) were retrieved (156) and clustered using Kendall, Spearman's and Pearson's correlation with similar results being obtained. The results based on the Spearman's correlation are shown.

Prediction of BCR risk with individual lncRNAs. Elevations in the levels of IncRNA LOC400891 have been observed in tumors vs. prostate tissue (181). The upregulation increases BCR risk in patients (Table $\mathrm{V}$ ); its overexpression and knockdown accordingly enhance and inhibit PC cell proliferation in vitro. There is evidence to indicate a role of LOC400891 in the activation of the PI3K pathway (181). Nonetheless, the involvement of LOC400891 in PC and other cancer types has yet to be further investigated.

Similar observations have also been reported in IncRNA-ATB (Table V) (182). IncRNA-ATB is upregulated in TGF- $\beta$-induced EMT (183). The upregulation of lncRNA-ATB and its oncogenic activities have been reported in multiple cancer types, including hepatocellular carcinoma (HCC), gastric cancer, colorectal cancer (CRC), renal cellular carcinoma, breast cancer and others (184). Collectively, the association of lncRNA-ATB with BCR warrants further investigation, which should be conducted in context of the pathways (such as TGF- $\beta$ ) affected by lncRNA-ATB in the course of BCR development.

Increases in the levels of IncRNA LINC01296 are associated with BCR (Table V) (185). LINC01296 was first reported as a biomarker of CRC (186); its oncogenic activities and association with cancer progression were subsequently observed in bladder cancer $(187,188)$, gastric cancer (189), cholangiocarcinoma (190), breast cancer (191), non-small cell lung cancer (192), and others (193). LINC01296 facilitates tumorigenesis in part by sponging miR122-5P in HCC (194) and miR-5059 in cholangiocarcinoma, leading to MYCN activation (190).

Second chromosome locus associated with prostate-1 (SChLAP1; LINC00913) is upregulated in PC and promotes tumor invasion and metastasis (195). In a multicentre study involving 937 patients, SChLAP1 overexpression was associated with lethal PC (196). Of note, elevations in SChLAP1 expressoin have been shown to predict PSA relapse (Table V) (197), an event which has also been observed by others (179), and PC metastasis (198). While SChLAP1 has been reported to prevent the association of the SWI/SNF complex with chromatin and thereby inhibiting the complex-associated tumor suppression in PC (195), late development revealed a SWI/SNF-independent action of SChLAP1 in PC tumorigenesis (199); the mechanisms through which SChLAP1 affects $\mathrm{PC}$ require further investigation.

The lncRNA urothelial carcinoma-associated 1 (UCA1) marginally predicts the risk of BCR (200). The prediction is consistent with the associations of UCA1 with reductions in the 5-year disease-free survival in PC $(n=130 ; \mathrm{HR}$, 2.88; 95\% CI, 1.36-6.21; $\mathrm{P}=0.007)(200)$ and in overall survival $(\mathrm{n}=40, \mathrm{P}<0.001)(201)$. Additionally, the upregulation of UCA1 has also been shown to be a risk factor for the progression of ovarian cancer (202), gastric cancer (203), melanoma (204), pancreatic cancer (205), glioma (206) and others (207). Mechanistically, UCA1 facilitates PC at least in part through upregulations of ATF2 and CXCR4 by sponging miR-204 $(208,209)$. Intriguingly, UCA1 sequesters miR-204, leading to EMT in glioma, TGF- $\beta$ signaling in oral cancer and Sox4 actions in esophageal cancer (207); UCA1 also sponges other miRNAs in promoting tumorigenesis in other cancer types (207). In this regard, the association of UCA1 with BCR could be strengthened by consideration of UCA1-regulated oncogenic factors.

The downregulation of the IncRNA prostate cancer-associated transcript 7 (PCAT7) is an independent factor predicting BCR (Table V) (210), consistent with its reductions following advance in GS and its downregulations independently predicting metastasis (210). Similar clinical associations were also confirmed by a multicenter study, in which PCAT14 was found to be an independent risk factor of metastasis ( $\mathrm{n}=910$; HR, 0.56, 95\% CI, 0.41-0.71; $\mathrm{P}=1.09 \mathrm{e}-6)$, prostate cancer-specific survival (HR, 0.53; 95\% CI. 0.39-0.72; $\mathrm{P}=6.54 \mathrm{e}-5$ ) and overall survival (HR, 0.67; 95\% CI, 0.54-0.83; $\mathrm{P}=0.00019$ ) (211). Apart from these two investigations, the involvement of PCAT14 in PC and other cancer types has not yet been thoroughly examined; the potential mechanisms of PCAT14 downregulation and its impact on PC progression have yet to be reported. Nonetheless, it appears that PCAT14 affects tumorigenesis in a complex manner; in HCC, PCAT14 is upregulated and promotes HCC cell proliferation and invasion (212).

Stratification of BCR risk with multi-lncRNAs (lncRNA panels). Multi-lncRNA panels have been constructed to stratify the risk of BCR, including a 4-lncRNA (213), 5-lncRNA (214), 7-lncRNA (215) and 8-lncRNA panels (Table VI) (216). All these studies were bioinformatics analyses of the TCGA dataset using different modules and sub-datasets. Differentially expressed lncRNAs (DE-lncRNAs) in the setting of PCs vs. prostate tissues were derived, followed by selection for their associations with BCR using either univariate Cox analysis $(213,215,216)$ or the LASSO (least absolute shrinkage and selection operator) Cox regression (214); DE-lncRNAs with significant associations with BCR constituted the individual lncRNA panels (Table VI). Risk scores of these panels were 
Table V. Associations of lncRNAs with BCR.

\begin{tabular}{|c|c|c|c|c|}
\hline lncRNAs & Cohort (n) & HR (95\% CI) & P-value & (Refs.) \\
\hline LOC400891 & 81 & $2.12(1.23-3.64)^{\mathrm{a}}$ & 0.007 & $(181)$ \\
\hline IncRNA-ATB & 57 & $1.75(2.31-14.25)^{\mathrm{a}}$ & $<0.001$ & $(182)$ \\
\hline LINC01296 & 70 & $6.58(1.95-22.22)^{\mathrm{b}}$ & 0.002 & $(185)$ \\
\hline SChLAP1 & 157 & $2.34(1.29-4.27)^{\mathrm{b}}$ & 0.005 & (197) \\
\hline UCA1 & 209 & $2.73(0.97-7.63)^{\mathrm{b}}$ & 0.056 & $(200)$ \\
\hline PCAT14 & 585 & $0.64(0.49-0.84)^{\mathrm{a}}$ & 0.00126 & $(210)$ \\
\hline
\end{tabular}

${ }^{a}$ Multivariate Cox analysis; ${ }^{b}$ univariate Cox analysis. HR, hazard ratio; BCR, biochemical recurrence.

Table VI. lncRNA panels predict BCR risk.

\begin{tabular}{|c|c|c|c|c|}
\hline lncRNA panels & Components & Cohort (n) & HR (95\% CI), P-value & (Refs.) \\
\hline 4-lncRNA & $\begin{array}{l}\text { RP11-108P20.4 } \\
\text { RP11-757G1.6 } \\
\text { RP11-347I19.8 } \\
\text { LINC01123 }\end{array}$ & 291 & $\begin{array}{l}3.33(1.59-6.97)^{\mathrm{a}}, \mathrm{P}=0.01 \\
3.13(1.45-6.78)^{\mathrm{b}}, \mathrm{P}=0.004\end{array}$ & (213) \\
\hline 5-lncRNA & $\begin{array}{l}\text { RP11-783K16.13 } \\
\text { RP11-727F15.11 } \\
\text { PRKAG2-AS1 } \\
\text { AC013460.1 } \\
\text { CRNDE }\end{array}$ & $\begin{array}{c}457 \\
343^{c} \\
141^{d}\end{array}$ & $\begin{array}{l}0.44(0.27-0.72)^{\mathrm{a}, \mathrm{c}}, \mathrm{P}<0.05 \\
0.22(0.09-0.56)^{\mathrm{a}, \mathrm{d}}, \mathrm{P}<0.05\end{array}$ & (214) \\
\hline 7-lncRNA & $\begin{array}{l}\text { SNHG1 } \\
\text { CRNDE } \\
\text { CTC-296K1.4 } \\
\text { UBNX10-AS1 } \\
\text { PART1 } \\
\text { CTC-296K1.3 } \\
\text { PGM5-AS1 }\end{array}$ & 457 & $0.32(0.2-0.52), \mathrm{P}<0.001$ & $(215)$ \\
\hline 8-IncRNA & $\begin{array}{l}\text { PCAT7 } \\
\text { SLC12A9-AS1 } \\
\text { RGMB-AS1 } \\
\text { PCAT1 } \\
\text { AP002992.1 } \\
\text { AC025265.1 } \\
\text { LINC00593 } \\
\text { AC005632.2 }\end{array}$ & $\begin{array}{l}307 \\
184^{\mathrm{d}} \\
123^{\mathrm{d}}\end{array}$ & $\begin{array}{l}2.19(1.67-2.88)^{\mathrm{a}, \mathrm{c}}, \mathrm{P}<0.0001 \\
2.19(1.49-3.22)^{\mathrm{b}, \mathrm{c}}, \mathrm{P}<0.0001\end{array}$ & $(216)$ \\
\hline
\end{tabular}

aUnivariate Cox analysis; ' ${ }^{\mathrm{b}}$ multivariate Cox analysis; ' ${ }^{\mathrm{a}}$ discovery set; ${ }^{\mathrm{d}}$ validation set. HR, hazard ratio; BCR, biochemical recurrence.

used to stratify the risk of BCR; the scores were calculated based on the following formula: Risk scores $=\operatorname{sum}\left(\operatorname{coef}_{\mathrm{i}} \mathrm{x}\right.$ DE-lncRNA $A_{i}$, where DE-lncRNA ${ }_{i}$ is the $i^{\text {th }}$ DE-lncRNA expression $(i=1, \ldots n)$ and $\operatorname{coef}_{i}$ is the Cox coefficient of DE-lncRNAi (213-216).

These IncRNA panels (Table VI) are novel. In the 4-IncRNA panel, only LINC01123 was reported in a prognostic lncRNA panel of head and neck squamous cell carcinoma (217). The lncRNA colorectal neoplasial differentially expressed (CRNDE) of the 5-lncRNA panel (Table VI) has been relatively well studied ( $n=72$ in PubMed under 'CRNDE' AND 'Cancer'). CRNDE is upregulated in CRC, glioma, HCC, lung cancer, ovarian cancer, breast cancer and others; it may play a role in cell proliferation, migration, invasion and apoptosis (218). Apart from CRNDE, other lncRNAs of the 5-lncRNA panel have not yet been reported, at least to the best of our knowledge.

In the 7-lncRNA panel (Table VI), small nucleolar RNA host gene 1 (SNHG1) was reported to upregulate CDK7 by sponging miR-199-3p, thereby enhancing PC cell proliferation (219); its involvement in cancer has been widely investigated ( $\mathrm{n}=64$ in PubMed under 'SNHG1' AND 'Cancer'). In addition to PC, SNHG1 is upregulated in CRC, liver cancer, lung cancer, gastric cancer and others; the 
upregulation correlated with adverse features of cancer (220) For PART1, PubMed has listed 16 articles related to 'PART1' AND 'Cancer'. The IncRNA prostate androgen-regulated transcript 1 (PART1) facilitates the progression of prostate cancer through the Toll-like receptor pathway (221) and non-small cell lung cancer via the JAK-STAT pathway (222); it displays oncogenic activities in bladder cancer (223). The lncRNA PGM5-AS1 has been limitedly studied $(n=4$ in PubMed under 'PGM5-AS1'). Evidence suggests PGM5-AS1 suppresses esophageal squamous cell carcinoma by facilitating PTEN actions though sponging miR-466 (224). Apart from SNHG1, CRNDE, PART1 and PGM5-AS1, the others in the 7-lncRNA panel (Table VI) have not yet been reported, at least to the best of our knowledge

In the 8-lncRNA panel (Table VI), the lncRNA PCAT7 has been investigated in 3 articles based on PubMed; evidence suggests that it enhances non-small cell lung cancer progression by inhibiting miR-134-5p (225). For the 1ncRNA PCAT1, there are 31 publications listed under PubMed that are related with 'PCAT1' and 'Cancer', in which 20 articles are PC-related. In PC, PCAT1 is a disease risk factor (226) and enhances CRPC by activating the AKT and NF- $x$ B signaling (227). PCAT1 was mapped to $8 \mathrm{q} 24$, a well-studied cancer (including PC) risk region (228). In line with this notion, PCAT1 promotes esophageal squamous cell carcinoma through sponging miR-326 (229), is a risk factor of CRC (230), and is associated with a poor prognosis in endometrial carcinoma (231). Apart from PCAT7, PGM5-AS1 and PCAT1, the others in the 8-lncRNA panel have not yet been reported, at least to the best of our knowledge.

Evaluation of BCR risk using lncRNAs: Perspectives and limitations. Since the discovery of the lncRNA H19 in 1991 (232) and Xist in 1992 (233), a large number and complex sets of lncRNAs have been identified; the discovery rate has been significantly accelerated since 2013 (174). Although the field of lncRNA is new, it is clear that lncRNA affects tumorigenesis via complex mechanisms at the genome, RNA and protein levels $(172,174)$. With respect to gene expression, the actions of lncRNA are likely complex. For instance, a prevalent mechanism is to associate with miRNAs, which prevent miRNAs from inhibiting mRNAs $(172,173)$. miRNAs are known to affect the expression of a large number of genes. Of note, miR-130b target genes are approaching 600 (61). It will thus be important to illustrate the major mechanisms, pathways and factors through which lncRNAs predict the risk of BCR; this will facilitate the formulation of lncRNA signatures with enhanced accuracy to stratify the risk of BCR. As an emerging and rapidly developing field, the biology of lncRNAs and the mechanisms mediating their biological actions have not been thoroughly investigated. In this regard, their potential as classifiers of BCR risk has yet to be fully recognized.

\section{Management of patients with biochemical recurrence}

PSA relapse offers the early identification of patients with failure following initial curative therapies with RP and RT. While BCR precedes clinical disease recurrence, the management of males with PSA relapse needs to consider multiple factors including tumor recurrence $(234,235)$. The nature of $\mathrm{BCR}$ is heterogeneous with local and distant recurrence (236).
Additionally, not all patients with BCR will progress to lethal disease (13). In addition to these variations are the improvements in risk stratification of BCR and metastasis as well as advances in salvage treatment. The heterogeneity of BCR along with the aforementioned advances complicates the management of patients with BCR. This topic has been recently discussed by several recent reviews (236-238). We also highlight the recent advances and suggest improvement on management of these patients in the context of BCR risk stratification using RNA-based biomarkers.

Detection of clinical recurrence following BCR. Recent developments have improved the diagnosis of clinical recurrence following BCR using the prostate-specific membrane antigen (PSMA)-based positron emission tomography (PET) imaging in comparison to conventional imaging modalities: Computed tomography (CT), magnetic resonance imaging (MRI) and bone scan $(239,240)$. PMSA (glutamate carboxypeptidase II) is an enzyme encoded by the folate hydrolase 1 (FOLHI) gene (https://en.wikipedia.org/wiki/Glutamate_carboxypeptidase_II) (241). It is mainly expressed in the prostate with weaker expressions detected in the brain, salivary gland and small intestine (242). PSMA expression is markedly upregulated in PC and the level of overexpression is associated with PC progression, including castration-resistant prostate adenocarcinoma (242-245). Nonetheless, its expression is suppressed in neuroendocrine prostate cancer (NEPC) (246), which will produce false negativities. False positivity is also a concern (246). Nonetheless, PSMA-PET has higher sensitivities in detecting recurrent sites at BCR in comparison to other imaging modalities (247). In a recent single-arm clinical trial on patients with BCR $(n=635)$ to assess the accuracy of ${ }^{68}$ Ga-PSMA-11 PET in detecting recurrent PCs, the overall detection rate was 75\% (475/635) and the PET-positive rates in different PSA groups were $38 \%$ for $<0.5 \mathrm{ng} / \mathrm{ml}, 57 \%$ for $0.5-<1.0 \mathrm{ng} / \mathrm{ml}, 84 \%$ for $1.0-<2.0 \mathrm{ng} / \mathrm{ml}, 86 \%$ for $2.0-<5.0 \mathrm{ng} / \mathrm{ml}$, and $97 \%$ for $\geq 5.0 \mathrm{ng} / \mathrm{ml}$ respectively (248). In a recent diagnostic study of 100 patients with BCR using ${ }^{18}$ F-PSMA-1007 PET/CT, the PET-positive rate was 86, 89, 100 and $100 \%$ for patients with PSA levels $\leq 0.5,0.51-1.0,1.0-2.0$, and $\geq 2.0 \mathrm{ng} / \mathrm{ml}$, respectively (249).

Clinical recurrence in the setting of BCR can also be at distant sites or metastasis. The diagnosis of metastasis can be facilitated using the Decipher test (GenomeDx Bioscience), a 22-gene genomic classifier (GC). This is an RNA-based gene panel consisting of coding and non-coding transcripts that function in multiple pathways including cell proliferation, adhesion, immune response, cell cycle progression and others (132). The Decipher GC predicts metastasis in patients following RP (132-134). In a recent multicenter study on 561 males with adverse pathological features, GC independently stratified the risk of prostate cancer-specific mortality (PCSM) following RP (250). The prediction was improved by combining GS with CAPRA-S (251) a classifier of BCR risk following PR $(21,22)$. In this regard, it would be expected that combination of GS with those RNA-based biomarkers discussed herein may strengthen the accuracy in predicting PCSM in the setting of RP; this will facilitate management of patients with BCR with respect to decision making on salvage treatment selection. 
Other biomarkers could also be considered. RP produces excellent outcomes in patients with localized low- and intermediate-risk PCs. However, the biochemical relapse rates for high-risk localized disease [PSA $>20 \mathrm{ng} / \mathrm{ml}, \mathrm{GS}>7$, or cT2c (3)] can increase to $50-80 \%$ (252). Males with high-risk tumors can be managed with adjuvant therapy following RP; in a small group of patients $(n=127)$ treated with adjuvant hormone therapy, high level of PDL1 expression is an independent risk factor of BCR (253). The PDL1 expression status could facilitate the diagnosis of BCR following RP.

Salvage therapies following BCR. Treatment selection for patients with BCR depends on the site of recurrence and the extent of progression; this information will be derived using imaging and other assessment including biomarker-based (such as GS) risk evaluation and PSA changes (236). Life expectancy, quality of life (QOL) and the time span of approximately 8 years for metastatic progression from BCR $(7,13)$ are among the factors that affect treatment decision making $(237,254)$.

Salvage radiotherapy (SRT) to the prostate bed is commonly used in patients with BCR following RP; it controls biochemical failure in approximately 50\% cases, reduces distant metastasis and improves PCSM $(236,255,256)$. The PSA status can guide local salvage treatment. EAU-ESTRO-SIOG recommends surveillance and delayed SRT in males exhibiting an increase in PSA with a favorable prognostic setting $[\leq \mathrm{pT} 3 \mathrm{a}$; time to $\mathrm{BCR},>3$ years; PSA doubling time (DT), >12 months; and GS 57 ], and beginning SRT at PSA $<0.5 \mathrm{ng} / \mathrm{ml}$ (7). On the other hand, the National Comprehensive Cancer Network (NCCN) recommends the initiation of SRT with confirmed increasing PSA levels, and many favor SRT at PSA $0.2 \mathrm{ng} / \mathrm{ml}$ (238). For patients with BCR following RT, salvage RP is an option with confirmed local recurrence according to EAU-ESTRO-SIOG guidelines (7). Similarly, the prostate cancer guidelines from the European Association of Nuclear Medicine (EAU-EANM)-European Society of Urogenital Radiology (ESTRO-ESUR)-SIOG classify males with BCR into a low-risk [PSA-DT $>1$ year and pathological GS (pGS) $<8$ or International Society of Urological Pathology (ISUP) grade <4] and high-risk group (PSA-DT $\leq 1$ year, pGS 8-10 or ISUP grade 4-5) for biological recurrence following RP or a low-risk [IBF (interval from primary therapy to biochemical failure) $>18$ months and biopsy GC (bGS) $<8$ or ISUP grade $<4$ ] and high-risk (IBF $\leq 18$ months and ) groups (pGS 8-10 or ISUP grade 4-5) (254). The stratification was recently validated based on the 5-year risk of developing metastasis and PCSM in a large cohort of patients with BCR $(n=1,040)$ (257). The guidelines call for the surveillance for males with BCR in the low-risk group and salvage ADT should not be given to these patients (254). It appears that SRT plus hormone therapy (bicalutamide) improved the outcome $(258,259)$. The risk of metastasis following SRT in patients with BCR can be stratified using Decipher GC (260). It is thus possible to assign patients with BCR following RP with combination therapy of SRT and ADT based on GC scores. Following this logic, whether incorporating BCR risk stratification with GS will enhance the decision making warrants further investigations in the future.

\section{Perspectives}

$\mathrm{BCR}$ precedes clinical disease recurrence and is significantly associated with increases in metastasis development and CRPC $(13,14,261)$, conditions to which our knowledge and ability to intervene remain poor. While more than half of patients with high-risk PCs will experience BCR following RP (252), the curative therapy yields good results in males with low- and intermediate-risk tumors. Accurately predicting the risk of BCR is thus highly relevant in the management of these patients. In view of the metastasis progression following $\mathrm{BCR}$, the stratification of the risk of BCR also contributes to the management of males with PSA relapse (please see section above entitled 'Salvage therapies following BCR'). Collectively, the effective evaluation of the risk of BCR is an essential aspect of patient management. With this recognition, a major research focus has been searching for biomarkers to robustly assess BCR risk, which is evident by 2,502 articles listed under 'prostate cancer' AND 'biomarker' AND 'biochemical recurrence' by PubMed. However, none of these had succeeded in progressing to routine clinical application (262); this clearly outlines the challenges in the identification of effective biomarkers.

While individual biomarkers, regardless of whether they are clinical feature-, DNA-, RNA-, and protein-based, may display a significant association with BCR, it is unlikely that they can effectively stratify BCR risk individually. BCR is regulated by complex mechanisms, which is likely an attribute to the lack of overlapping genes between two commercially available multigene panels, Oncotype DX GPS and Prolaris, despite both assessing the risk of BCR $(135,137)$. It is thus conceivable that multigene panels will certainly enhance the effectiveness of BCR biomarkers. In this regard, it will be intriguing to systemically analyze Oncotype DX, Prolaris and other RNA-based biomarkers along with clinical feature-based (PSA, GS, stage, surgical margin status, lymph node status and others) BCR risk classifiers (CAPRA-S, Walz nomogram, and others) for the stratification of the risk of BCR. This may produce a much more robust system, covering essential pathways leading to $\mathrm{BCR}$, in predicting the risk of $\mathrm{BCR}$, which will greatly improve patient management with prostate cancer.

Another avenue worthy of exploration for the improvement of the stratification of the risk of BCR is the process of DNA damage response (DDR). Genomic instability is a hallmark of cancer and the driving force of cancer progression (263); genomic stability is maintained through DDR by coordinating checkpoint activation and DNA lesion repairs (264-266). It is surprising that factors in DDR regulation have not been intensively investigated for their biomarker potential.

The same situation applies to stromal factors. While a variety of tumor properties have been examined for prognostic purposes, the stromal contributions and the communications between he stroma and tumor have not been actively determined for biomarker purposes. A potential mechanism causing stromal alterations is through PC-associated metabolic reprogramming, which results in the accumulation of metabolic intermediates (267); these materials affect gene expression via epigenetic alterations (268). Metabolic reprogramming is a well-established mechanism supporting not 
only tumorigenesis, but also cancer progression $(36,267,268)$. In this regard, PC-associated metabolic alterations will have a prognostic potential which has been recently reviewed by Lucarelli et al (267). It is of interest that PCs can be grouped into two metabolic profiles: Phopho-AKT ${ }^{\text {high }} / \mathrm{MYC}^{\text {low }}$ or phopho-AKT ${ }^{\text {low }} / \mathrm{MYC}^{\text {high }}$ with the former and latter affecting the glucose-related processes and lipid metabolism, respectively (269). Nonetheless, the prognostic potential of $\mathrm{PC}$-associated metabolic alterations remains complex. For instance, the AKT- and MYC-related metabolic signatures are not associated with GS and pathological stage (269); of note, neither MYC overexpression nor AKT phosphorylation displays a strong prognostic potential in PC $(267,270,271)$. While increases in body mass index (BMI) and obesity are associated with PC-related mortality (272), there is also evidence to support the reverse association (273). A similar situation also applies to the association between cholesterol and PC progression. A meta-analysis of 27 clinical studies up to 2012 with a pooled population of 1.8 million males revealed a $7 \%$ reduction in PC cases and a $20 \%$ decrease in PC progression in statin users (274). Statins were reported to reduce BCR following RT (275) and RP (276). However, other studies observed no clinical benefits in males with PC who were statin users $(277,278)$ and reported statins having no impact on BCR following RP (279). Clearly, the prognostic values of metabolic alterations in $\mathrm{PC}$ warrant further investigations.

The plasticity of cancer, including PC, presents a major challenge not only in cancer therapy, but also in assessing the risk of cancer progression. Cancer plasticity is regulated by complex mechanisms, including those functioning in CSCs and DDR (280,281). It is noteworthy that BMI1, a well-established factor in maintaining CSC (282), also compromises genomic instability via attenuating ATM and ATR functions (264,283-285). In this regard, DDR regulations and stroma-cancer cell communications, both of which contribute to cancer plasticity, should be actively brought into the picture of BCR risk assessment; with these components incorporated, the ability to accurately classify BCR risk will likely be significantly improved.

PC is associated with high levels of intratumoral and intertumoral heterogeneity (286). This aspect has not been given sufficient consideration and should be pursued in PC biomarker development. Collaborative efforts involving multiple institutes in sharing materials and expertise will certainly be helpful to achieve this goal.

\section{Acknowledgements}

Not applicable.

\section{Funding}

DT was supported by grants from the Cancer Research Society, Canadian Cancer Society (grant no. 319412), CIHR and by funds from the Urological Cancer Center for Research and Innovation (UCCRI). PM was supported by CIHR. YG was supported by Studentship provided by Ontario Graduate Scholarships and Research Institute of St. Joe's Hamilton.

\section{Availability of data and materials}

Not applicable.

\section{Authors' contributions}

XL, AK, HX, PM and DT were involved in the conception of the study. XL, YG and MJC were involved in the literature search. XL, PM and DT were involved in the writing and preparation of the original draft of the manuscript. All authors were involved in the writing and reviewing of the article. YG, PM and DT were involved in the writing and editing of the article. DT supervised the study. All authors have read and approved the final manuscript.

\section{Ethics approval and consent to participate}

Not applicable.

\section{Patient consent for publication}

Not applicable.

\section{Competing interests}

The authors declare that they have no competing interests.

\section{References}

1. Siegel RL, Miller KD and Jemal A: Cancer statistics, 2019. CA Cancer J Clin 69: 7-34, 2019.

2. Heidenreich A, Bastian PJ, Bellmunt J, Bolla M, Joniau S, van der Kwast T, Mason M, Matveev V, Wiegel T, Zattoni F, et al: EAU guidelines on prostate cancer. Part II: Treatment of advanced, relapsing, and castration-resistant prostate cancer. Eur Urol 65: 467-479, 2014.

3. Mottet N, Bellmunt J, Bolla M, Briers E, Cumberbatch MG, De Santis M, Fossati N, Gross T, Henry AM, Joniau S, et al: EAU-ESTRO-SIOG Guidelines on prostate cancer. Part 1: Screening, diagnosis, and local treatment with curative intent. Eur Urol 71: 618-629, 2017.

4. Bill-Axelson A, Holmberg L, Garmo H, Rider JR, Taari K, Busch C, Nordling S, Häggman M, Andersson SO, Spångberg A, et al: Radical prostatectomy or watchful waiting in early prostate cancer. N Engl J Med 370: 932-942, 2014.

5. Hayes JH, Ollendorf DA, Pearson SD, Barry MJ, Kantoff PW, Lee PA and McMahon PM: Observation versus initial treatment for men with localized, low-risk prostate cancer: A cost-effectiveness analysis. Ann Intern Med 158: 853-860, 2013.

6. Godtman RA, Holmberg E, Khatami A, Stranne J and Hugosson J: Outcome following active surveillance of men with screen-detected prostate cancer. Results from the Göteborg randomised population-based prostate cancer screening trial. Eur Urol 63: 101-107, 2013.

7. Cornford P, Bellmunt J, Bolla M, Briers E, De Santis M, Gross T, Henry AM, Joniau S, Lam TB, Mason MD, et al: EAU-ESTRO-SIOG Guidelines on prostate cancer. Part II: Treatment of relapsing, metastatic, and castration-resistant prostate cancer. Eur Urol 71: 630-642, 2017.

8. Zaorsky NG, Raj GV, Trabulsi EJ, Lin J and Den RB: The dilemma of a rising prostate-specific antigen level after local therapy: What are our options? Semin Oncol 40: 322-336, 2013.

9. Roehl KA, Han M, Ramos CG, Antenor JA and Catalona WJ: Cancer progression and survival rates following anatomical radical retropubic prostatectomy in 3,478 consecutive patients: Long-term results. J Urol 172: 910-914, 2004.

10. Freedland SJ, Humphreys EB, Mangold LA, Eisenberger M, Dorey FJ, Walsh PC and Partin AW: Risk of prostate cancer-specific mortality following biochemical recurrence after radical prostatectomy. JAMA 294: 433-439, 2005. 
11. Kupelian PA, Mahadevan A, Reddy CA, Reuther AM and Klein EA: Use of different definitions of biochemical failure after external beam radiotherapy changes conclusions about relative treatment efficacy for localized prostate cancer. Urology 68 : 593-598, 2006.

12. Artibani W, Porcaro AB, De Marco V, Cerruto MA and Siracusano S: Management of biochemical recurrence after primary curative treatment for prostate cancer: A review. Urol Int 100: 251-262, 2018.

13. Pound CR, Partin AW, Eisenberger MA, Chan DW, Pearson JD and Walsh PC: Natural history of progression after PSA elevation following radical prostatectomy. JAMA 281: 1591-1597, 1999.

14. Boorjian SA, Thompson RH, Tollefson MK, Rangel LJ, Bergstralh EJ, Blute ML and Karnes RJ: Long-term risk of clinical progression after biochemical recurrence following radical prostatectomy: The impact of time from surgery to recurrence. Eur Urol 59: 893-899, 2011.

15. Heinlein CA and Chang C: Androgen receptor in prostate cancer. Endoc Rev 25: 276-308, 2004.

16. Tannock IF, de Wit R, Berry WR, Horti J, Pluzanska A Chi KN, Oudard S, Théodore C, James ND, Turesson I, et al: Docetaxel plus prednisone or mitoxantrone plus prednisone for advanced prostate cancer. N Engl J Med 351: 1502-1512, 2004.

17. Berthold DR, Pond GR, Soban F, de Wit R, Eisenberger M and Tannock IF: Docetaxel plus prednisone or mitoxantrone plus prednisone for advanced prostate cancer: Updated survival in the TAX 327 study. J Clin Oncol 26: 242-245, 2008.

18. de Bono JS, Logothetis CJ, Molina A, Fizazi K, North S, Chu L, Chi KN, Jones RJ, Goodman OB Jr, Saad F, et al: Abiraterone and increased survival in metastatic prostate cancer. N Engl J Med 364: 1995-2005, 2011.

19. Scher HI, Fizazi K, Saad F, Taplin ME, Sternberg CN, Miller K de Wit R, Mulders P, Chi KN, Shore ND, et al: Increased survival with enzalutamide in prostate cancer after chemotherapy. N Engl J Med 367: 1187-1197, 2012.

20. Cooperberg MR, Pasta DJ, Elkin EP, Litwin MS, Latini DM, Du Chane J and Carroll PR: The University of California, San Francisco Cancer of the Prostate Risk Assessment score: A straightforward and reliable preoperative predictor of disease recurrence after radical prostatectomy. J Urol 173: 1938-1942, 2005

21. Brajtbord JS, Leapman MS and Cooperberg MR: The CAPRA Score at 10 Years: Contemporary perspectives and analysis of supporting studies. Eur Urol 71: 705-709, 2017.

22. Cooperberg MR, Hilton JF and Carroll PR: The CAPRA-S score: A straightforward tool for improved prediction of outcomes after radical prostatectomy. Cancer 117: 5039-5046, 2011.

23. D'Amico AV, Whittington R, Malkowicz SB, Schultz D, Blank K, Broderick GA, Tomaszewski JE, Renshaw AA, Kaplan I, Beard CJ and Wein A: Biochemical outcome after radical prostatectomy, external beam radiation therapy, or interstitial radiation therapy for clinically localized prostate cancer. JAMA 280 : 969-974, 1998

24. Dillioglugil O, Leibman BD, Kattan MW, Seale-Hawkins C, Wheeler TM and Scardino PT: Hazard rates for progression after radical prostatectomy for clinically localized prostate cancer. Urology 50: 93-99, 1997.

25. Han M, Partin AW, Zahurak M, Piantadosi S, Epstein JI and Walsh PC: Biochemical (prostate specific antigen) recurrence probability following radical prostatectomy for clinically localized prostate cancer. J Urol 169: 517-523, 2003.

26. Simmons MN, Stephenson AJ and Klein EA: Natural history of biochemical recurrence after radical prostatectomy: Risk assessment for secondary therapy. Eur Urol 51: 1175-1184, 2007.

27. Lange PH, Ercole CJ, Lightner DJ, Fraley EE and Vessella R: The value of serum prostate specific antigen determinations before and after radical prostatectomy. J Urol 141: 873-879, 1989.

28. Kim DK, Koo KC, Lee KS, Hah YS, Rha KH, Hong SJ and Chung BH: Time to disease recurrence is a predictor of metastasis and mortality in patients with High-risk prostate cancer who achieved undetectable prostate-specific antigen following Robot-assisted radical prostatectomy. J Korean Med Sci 33: e285, 2018.

29. Walz J, Chun FK, Klein EA, Reuther A, Saad F, Graefen M, Huland $\mathrm{H}$ and Karakiewicz PI: Nomogram predicting the probability of early recurrence after radical prostatectomy for prostate cancer. J Urol 181: 601-608, 2009.
30. Pompe RS, Bandini M, Preisser F, Marchioni M, Zaffuto E, Tian Z, Salomon G, Schlomm T, Huland H, Graefen M, et al: Contemporary approach to predict early biochemical recurrence after radical prostatectomy: Update of the Walz nomogram. Prostate Cancer Prostatic Dis 21: 386-393, 2018.

31. Sherr CJ: Cancer cell cycles. Science 274: 1672-1677, 1996.

32. Ross AE, D'Amico AV and Freedland SJ: Which, when and why? Rational use of tissue-based molecular testing in localized prostate cancer. Prostate Cancer Prostatic Dis 19: 1-6, 2016.

33. Carneiro A, Barbosa ARG, Takemura LS, Kayano PP, Moran NKS, Chen CK, Wroclawski ML, Lemos GC, da Cunha IW, Obara MT, et al: The role of immunohistochemical analysis as a tool for the diagnosis, prognostic evaluation and treatment of prostate cancer: A systematic review of the literature. Front Oncol 8: 377, 2018.

34. Iatropoulos MJ and Williams GM: Proliferation markers. Exp Toxicol Pathol 48: 175-181, 1996.

35. Fantony JJ, Howard LE, Csizmadi I, Armstrong AJ, Lark AL, Galet C, Aronson WJ and Freedland SJ: Is Ki67 prognostic for aggressive prostate cancer? A multicenter real-world study. Biomark Med 12: 727-736, 2018.

36. Wong N, Ojo D, Yan J and Tang D: PKM2 contributes to cancer metabolism. Cancer Lett 356: 184-191, 2015.

37. Carabet LA, Rennie PS and Cherkasov A: Therapeutic inhibition of myc in cancer. Structural bases and computer-aided drug discovery approaches. Int J Mol Sci 20: pii: E120, 2018.

38. Gurel B, Iwata T, Koh CM, Jenkins RB, Lan F, Van Dang C, Hicks JL, Morgan J, Cornish TC, Sutcliffe S, et al: Nuclear MYC protein overexpression is an early alteration in human prostate carcinogenesis. Mod Pathol 21: 1156-1167, 2008.

39. Baena-Del Valle JA, Zheng Q, Esopi DM, Rubenstein M, Hubbard GK, Moncaliano MC, Hruszkewycz A, Vaghasia A Yegnasubramanian S, Wheelan SJ, et al: MYC drives overexpression of telomerase RNA (hTR/TERC) in prostate cancer. J Pathol 244: 11-24, 2018.

40. Hubbard GK, Mutton LN, Khalili M, McMullin RP, Hicks JL, Bianchi-Frias D, Horn LA, Kulac I, Moubarek MS, Nelson PS, et al: Combined MYC activation and pten loss are sufficient to create genomic instability and lethal metastatic prostate cancer. Cancer Res 76: 283-292, 2016.

41. Tomlins SA, Rhodes DR, Perner S, Dhanasekaran SM, Mehra R, Sun XW, Varambally S, Cao X, Tchinda J, Kuefer R, et al: Recurrent fusion of TMPRSS2 and ETS transcription factor genes in prostate cancer. Science 310: 644-648, 2005.

42. Park K, Tomlins SA, Mudaliar KM, Chiu YL, Esgueva R, Mehra R, Suleman K, Varambally S, Brenner JC, MacDonald T, et al: Antibody-based detection of ERG rearrangement-positive prostate cancer. Neoplasia 12: 590-598, 2010.

43. Inoue T, Segawa T, Shiraishi T, Yoshida T, Toda Y, Yamada T, Kinukawa N, Kinoshita H, Kamoto T and Ogawa O: Androgen receptor, $\mathrm{Ki} 67$, and p53 expression in radical prostatectomy specimens predict treatment failure in Japanese population. Urology 66: 332-337, 2005

44. Osman I, Drobnjak M, Fazzari M, Ferrara J, Scher HI and Cordon-Cardo C: Inactivation of the p53 pathway in prostate cancer: Impact on tumor progression. Clin Cancer 5: 2082-2088, 1999.

45. Hemminki K: Familial risk and familial survival in prostate cancer. World J Urol 30: 143-148, 2012.

46. Castro E, Goh C, Olmos D, Saunders E, Leongamornlert D, Tymrakiewicz M, Mahmud N, Dadaev T, Govindasami K, Guy M, et al: Germline BRCA mutations are associated with higher risk of nodal involvement, distant metastasis, and poor survival outcomes in prostate cancer. J Clin Oncol 31: 1748-1757, 2013.

47. Castro E, Goh C, Leongamornlert D, Saunders E, Tymrakiewicz M, Dadaev T, Govindasami K, Guy M, Ellis S, Frost D, et al: Effect of BRCA mutations on metastatic relapse and Cause-specific survival after radical treatment for localised prostate cancer. Eur Urol 68: 186-193, 2015.

48. Taylor RA, Fraser M, Livingstone J, Espiritu SM, Thorne H, Huang V, Lo W, Shiah YJ, Yamaguchi TN, Sliwinski A, et al: Germline BRCA2 mutations drive prostate cancers with distinct evolutionary trajectories. Nat Commun 8: 13671, 2017.

49. Pritchard CC, Mateo J, Walsh MF, De Sarkar N, Abida W, Beltran H, Garofalo A, Gulati R, Carreira S, Eeles R, et al: Inherited DNA-repair gene mutations in men with metastatic prostate cancer. N Engl J Med 375: 443-453, 2016. 
50. Cooperberg MR, Erho N, Chan JM, Feng FY, Fishbane N, Zhao SG, Simko JP, Cowan JE, Lehrer J, Alshalalfa M, et al: The diverse genomic landscape of clinically Low-risk prostate cancer. Eur Urol 74: 444-452, 2018

51. Curtis C, Shah SP, Chin SF, Turashvili G, Rueda OM, Dunning MJ, Speed D, Lynch AG, Samarajiwa S, Yuan Y, et al: The genomic and transcriptomic architecture of 2,000 breast tumours reveals novel subgroups. Nature 486: 346-352, 2012

52. Evans JR, Zhao SG, Chang SL, Tomlins SA, Erho N, Sboner A, Schiewer MJ, Spratt DE, Kothari V, Klein EA, et al: Patient-level DNA damage and repair pathway profiles and prognosis after prostatectomy for high-risk prostate cancer. JAMA Oncol 2 471-480, 2016

53. Magi-Galluzzi C, Tsusuki T, Elson P, Simmerman K, LaFargue $C$ Esgueva R, Klein E, Rubin MA and Zhou M: TMPRSS2-ERG gene fusion prevalence and class are significantly different in prostate cancer of Caucasian, African-American and Japanese patients. Prostate 71: 489-497, 2011

54. Ren S, Peng Z, Mao JH, Yu Y, Yin C, Gao X, Cui Z, Zhang J, Yi K, $\mathrm{Xu}$ W, et al: RNA-seq analysis of prostate cancer in the Chinese population identifies recurrent gene fusions, cancer-associated long noncoding RNAs and aberrant alternative splicings. Cell Res 22: 806-821, 2012.

55. Song $\mathrm{C}$ and Chen $\mathrm{H}$ : Predictive significance of TMRPSS2-ERG fusion in prostate cancer: A meta-analysis. Cancer Cell Int 18 177,2018

56. Shamseer L, Moher D, Clarke M, Ghersi D, Liberati A Petticrew M, Shekelle P and Stewart LA; PRISMA-P Group: Preferred reporting items for systematic review and meta-analysis protocols (PRISMA-P) 2015: Elaboration and explanation. BMJ 350: g7647, 2015.

57. Moher D, Shamseer L, Clarke M, Ghersi D, Liberati A, Petticrew M, Shekelle P and Stewart LA; PRISMA-P Group: Preferred reporting items for systematic review and meta-analysis protocols (PRISMA-P) 2015 statement. Syst Rev 4: 1, 2015.

58. Nam RK, Benatar T, Wallis CJ, Amemiya Y, Yang W, Garbens A, Naeim M, Sherman C, Sugar L and Seth A: MiR-301a regulates E-cadherin expression and is predictive of prostate cancer recurrence. Prostate 76: 869-884, 2016

59. Li T, Li RS, Li YH, Zhong S, Chen YY, Zhang CM, Hu MM and Shen ZJ: miR-21 as an independent biochemical recurrence predictor and potential therapeutic target for prostate cancer. J Urol 187: 1466-1472, 2012

60. Sun X, Yang Z, Zhang Y, He J, Wang F, Su P, Han J, Song Z and Fei Y: Prognostic implications of tissue and serum levels of microRNA-128 in human prostate cancer. Int J Clin Exp Pathol 8: 8394-8401, 2015.

61. Aakula A, Kohonen P, Leivonen SK, Mäkelä R, Hintsanen P, Mpindi JP, Martens-Uzunova E, Aittokallio T, Jenster G, Perälä M, et al: Systematic identification of MicroRNAs that impact on proliferation of prostate cancer cells and display changed expression in tumor tissue. Eur Urol 69: 1120-1128, 2016.

62. Ling $X H$, Han ZD, Xia D, He HC, Jiang FN, Lin ZY, Fu X, Deng YH, Dai QS, Cai C, et al: MicroRNA-30c serves as an independent biochemical recurrence predictor and potential tumor suppressor for prostate cancer. Mol Biol Rep 41: 2779-2788, 2014

63. Avgeris M, Stravodimos K, Fragoulis EG and Scorilas A: The loss of the tumour-suppressor miR-145 results in the shorter disease-free survival of prostate cancer patients. Br J Cancer 108: 2573-2581, 2013

64. Tao Z, Xu S, Ruan H, Wang T, Song W, Qian L and Chen K: MiR-195/-16 family enhances radiotherapy via T cell activation in the tumor microenvironment by blocking the PD-L1 immune checkpoint. Cell Physiol Biochem 48: 801-814, 2018.

65. Shibue T and Weinberg RA: EMT, CSCs, and drug resistance: The mechanistic link and clinical implications. Nat Rev Clin Oncol 14: 611-629, 2017.

66. Mei W, Lin X, Kapoor A, Gu Y, Zhao K and Tang D: The contributions of prostate cancer stem cells in prostate cancer initiation and metastasis. Cancers (Basel) 11: pii: E434, 2019.

67. Yang Y, Guo JX and Shao ZQ: miR-21 targets and inhibits tumor suppressor gene PTEN to promote prostate cancer cell proliferation and invasion: An experimental study. Asian Pac J Trop Med 10: 87-91, 2017.

68. Zhao Y, Yin Z, Li H, Fan J, Yang S, Chen C and Wang DW: MiR-30c protects diabetic nephropathy by suppressing epithelial-to-mesenchymal transition in db/db mice. Aging Cell 16: $387-400,2017$
69. Zhu C, Hou X, Zhu J, Jiang C and Wei W: Expression of miR-30c and miR-29b in prostate cancer and its diagnostic significance. Oncol Lett 16: 3140-3144, 2018.

70. Sachdeva M, Liu Q, Cao J, Lu Z and Mo YY: Negative regulation of miR-145 by C/EBP- $\beta$ through the Akt pathway in cancer cells. Nucleic Acids Res 40: 6683-6692, 2012.

71. Ozen M, Creighton CJ, Ozdemir M and Ittmann M: Widespread deregulation of microRNA expression in human prostate cancer. Oncogene 27: 1788-1793, 2008

72. Wach S, Nolte E, Szczyrba J, Stöhr R, Hartmann A, Ørntoft T, Dyrskjøt L, Eltze E, Wieland W and Keck B: MicroRNA profiles of prostate carcinoma detected by multiplatform microRNA screening. Int J Cancer 130: 611-621, 2012.

73. Liu B, Li J and Cairns MJ: Identifying miRNAs, targets and functions. Brief Bioinform 15: 1-19, 2014.

74. Chen CS, Huang CY, Huang SP, Lin VC, Yu CC, Chang TY and Bao BY: Genetic interaction analysis of TCF7L2 for biochemical recurrence after radical prostatectomy in localized prostate cancer. Int J Med Sci 12: 243-247, 2015.

75. Malhotra S, Lapointe J, Salari K, Higgins JP, Ferrari M, Montgomery K, van de Rijn M, Brooks JD and Pollack JR: A tri-marker proliferation index predicts biochemical recurrence after surgery for prostate cancer. PLoS One 6: e20293, 2011.

76. Mo RJ, Han ZD, Liang YK, Ye JH, Wu SL, Lin SX, Zhang YQ, Song SD, Jiang FN, Zhong WD and Wu CL: Expression of PD-L1 in tumor-associated nerves correlates with reduced CD8 ${ }^{+}$ tumor-associated lymphocytes and poor prognosis in prostate cancer. Int J Cancer 144: 3099-3110, 2019.

77. Gevensleben H, Dietrich D, Golletz C, Steiner S, Jung M, Thiesler T, Majores M, Stein J, Uhl B, Müller S, et al: The immune checkpoint regulator PD-L1 is highly expressed in aggressive primary prostate cancer. Clin Cancer Res 22: 1969-1977, 2016.

78. Luo JH, Yu YP, Cieply K, Lin F, Deflavia P, Dhir R, Finkelstein S, Michalopoulos G and Becich M: Gene expression analysis of prostate cancers. Mol Carcinog 33: 25-35, 2002.

79. Sandsmark E, Andersen MK, Bofin AM, Bertilsson H, Drabløs F, Bathen TF, Rye MB and Tessem MB: SFRP4 gene expression is increased in aggressive prostate cancer. Sci Rep 7: 14276, 2017.

80. Mortensen MM, Høyer S, Lynnerup AS, Ørntoft TF, Sørensen KD, Borre M and Dyrskjøt L: Expression profiling of prostate cancer tissue delineates genes associated with recurrence after prostatectomy. Sci Rep 5: 16018, 2015.

81. Mazzoni SM and Fearon ER: AXIN1 and AXIN2 variants in gastrointestinal cancers. Cancer Lett 355: 1-8, 2014.

82. Li J, Hu SB, Wang LY, Zhang X, Zhou X, Yang B, Li JH, Xiong J, Liu N, Li Y, et al: Autophagy-dependent generation of Axin2+ cancer stem-like cells promotes hepatocarcinogenesis in liver cirrhosis. Oncogene 36: 6725-6737, 2017.

83. Martins-Neves SR, Corver WE, Paiva-Oliveira DI, van den Akker BE, Briaire-de-Bruijn IH, Bovée JV, Gomes CM and Cleton-Jansen AM: Osteosarcoma stem cells have active Wnt/ $\beta$-catenin and overexpress SOX2 and KLF4. J Cell Physiol 231: 876-886, 2016.

84. Lim X, Tan SH, Yu KL, Lim SB and Nusse R: Axin2 marks quiescent hair follicle bulge stem cells that are maintained by autocrine Wnt $/ \beta$-catenin signaling. Proc Natl Acad Sci USA 113: E1498-E1505, 2016.

85. Ma C, Liu C, Huang P, Kaku H, Chen J, Guo K, Ueki H, Sakai A, Nasu Y, Kumon H, et al: Significant association between the Axin2 rs2240308 single nucleotide polymorphism and the incidence of prostate cancer. Oncol Lett 8: 789-794, 2014.

86. Hu BR, Fairey AS, Madhav A, Yang D, Li M, Groshen S, Stephens C, Kim PH, Virk N, Wang L, et al: AXIN2 expression predicts prostate cancer recurrence and regulates invasion and tumor growth. Prostate 76: 597-608, 2016.

87. Nordby Y, Richardsen E, Rakaee M, Ness N, Donnem T, Patel HR, Busund LT, Bremnes RM and Andersen S: High expression of PDGFR- $\beta$ in prostate cancer stroma is independently associated with clinical and biochemical prostate cancer recurrence. Sci Rep 7: 43378, 2017.

88. Paulsson J, Ehnman M and Östman A: PDGF receptors in tumor biology: Prognostic and predictive potential. Future Oncol 10: 1695-1708, 2014

89. Demidenko R, Daniunaite K, Bakavicius A, Sabaliauskaite R, Skeberdyte A, Petroska D, Laurinavicius A, Jankevicius F, Lazutka JR and Jarmalaite S: Decreased expression of MT1E is a potential biomarker of prostate cancer progression. Oncotarget 8: 61709-61718, 2017.

90. Si M and Lang J: The roles of metallothioneins in carcinogenesis. J Hematol Oncol 11: 107, 2018 
91. Tse KY, Liu VW, Chan DW, Chiu PM, Tam KF, Chan KK, Liao XY, Cheung AN and Ngan HY: Epigenetic alteration of the metallothionein $1 \mathrm{E}$ gene in human endometrial carcinomas. Tumour Biol 30: 93-99, 2009.

92. Subrungruanga I, Thawornkunob C, ChawalitchewinkoonPetmitrc P, Pairojkul C, Wongkham S and Petmitrb S: Gene expression profiling of intrahepatic cholangiocarcinoma. Asian Pac J Cancer Prev 14: 557-563, 2013.

93. Faller WJ, Rafferty M, Hegarty S, Gremel G, Ryan D, Fraga MF Esteller M, Dervan PA and Gallagher WM: Metallothionein 1E is methylated in malignant melanoma and increases sensitivity to cisplatin-induced apoptosis. Melanoma Res 20: 392-400, 2010.

94. Werynska B, Pula B, Muszczynska-Bernhard B, Gomulkiewicz A, Piotrowska A, Prus R, Podhorska-Okolow M, Jankowska R and Dziegiel P: Metallothionein 1F and 2A overexpression predicts poor outcome of non-small cell lung cancer patients. Exp Mol Pathol 94: 301-308, 2013.

95. Ferrario C, Lavagni P, Gariboldi M, Miranda C, Losa M, Cleris L, Formelli F, Pilotti S, Pierotti MA and Greco A: Metallothionein $1 \mathrm{G}$ acts as an oncosupressor in papillary thyroid carcinoma. Lab Invest 88: 474-481, 2008.

96. Takahashi M, Rhodes DR, Furge KA, Kanayama H, Kagawa S, Haab BB and Teh BT: Gene expression profiling of clear cell renal cell carcinoma: Gene identification and prognostic classification. Proc Natl Acad Sci USA 98: 9754-9759, 2001.

97. Jin R, Bay BH, Chow VT, Tan PH and Lin VC: Metallothionein $1 \mathrm{E}$ mRNA is highly expressed in oestrogen receptor-negative human invasive ductal breast cancer. Br J Cancer 83: 319-323, 2000.

98. Hur H, Ryu HH, Li CH, Kim IY, Jang WY and Jung S: Metallothinein 1E enhances glioma invasion through modulation matrix metalloproteinases-2 and 9 in U87MG mouse brain tumor model. J Korean Neurosurg Soc 59: 551-558, 2016.

99. Ryu HH, Jung S, Jung TY, Moon KS, Kim IY, Jeong YI, Jin SG, Pei J, Wen M and Jang WY: Role of metallothionein 1E in the migration and invasion of human glioma cell lines. Int J Oncol 41: 1305-1313, 2012.

100. Mavridis K, Stravodimos K and Scorilas A: Quantified KLK15 gene expression levels discriminate prostate cancer from benign tumors and constitute a novel independent predictor of disease progression. Prostate 73: 1191-1201, 2013.

101. Obiezu CV and Diamandis EP: Human tissue kallikrein gene family: Applications in cancer. Cancer Lett 224: 1-22, 2005

102. Tse BWC, Volpert M, Ratther E, Stylianou N, Nouri M, McGowan K, Lehman ML, McPherson SJ, Roshan-Moniri M, Butler MS, et al: Neuropilin-1 is upregulated in the adaptive response of prostate tumors to androgen-targeted therapies and is prognostic of metastatic progression and patient mortality. Oncogene 36: 3417-3427, 2017

103. Muhl L, Folestad EB, Gladh H, Wang Y, Moessinger C, Jakobsson L and Eriksson U: Neuropilin 1 binds PDGF-D and is a co-receptor in PDGF-D-PDGFR $\beta$ signaling. J Cell Sci 130 1365-1378, 2017.

104. Zhang L, Wang H, Li C, Zhao Y, Wu L, Du X and Han Z VEGF-A/Neuropilin 1 pathway confers cancer stemness via activating Wnt/ $\beta$-catenin axis in breast cancer cells. Cell Physiol Biochem 44: 1251-1262, 2017.

105. Latil A, Bièche I, Pesche S, Valéri A, Fournier G, Cussenot O and Lidereau R: VEGF overexpression in clinically localized prostate tumors and neuropilin-1 overexpression in metastatic forms. Int J Cancer 89: 167-171, 2000.

106. Talagas M, Uguen A, Garlantezec R, Fournier G, Doucet L, Gobin E, Marcorelles P, Volant A and DE Braekeleer M: VEGFR1 and NRP1 endothelial expressions predict distant relapse after radical prostatectomy in clinically localized prostate cancer. Anticancer Res 33: 2065-2075, 2013.

107. Li F, Xu Y and Liu RL: SAMD5 mRNA was overexpressed in prostate cancer and can predict biochemical recurrence after radical prostatectomy. Int Urol Nephrol 51: 443-451, 2019.

108. Matsuo T, Dat le T, Komatsu M, Yoshimaru T, Daizumoto K, Sone S, Nishioka Y and Katagiri T: Early growth response 4 is involved in cell proliferation of small cell lung cancer through transcriptional activation of its downstream genes. PLoS One 9: e113606, 2014.

109. Yagai T, Matsui S, Harada K, Inagaki FF, Saijou E, Miura Y, Nakanuma Y, Miyajima A and Tanaka M: Expression and localization of sterile alpha motif domain containing 5 is associated with cell type and malignancy of biliary tree. PLoS One 12: e0175355, 2017
110. Watanabe T, Kobunai T, Akiyoshi T, Matsuda K, Ishihara S and Nozawa K: Prediction of response to preoperative chemoradiotherapy in rectal cancer by using reverse transcriptase polymerase chain reaction analysis of four genes. Dis Colon Rectum 57: 23-31, 2014.

111. Wang Y, Shang Y, Li J, Chen W, Li G, Wan J, Liu W and Zhang M: Specific Eph receptor-cytoplasmic effector signaling mediated by SAM-SAM domain interactions. Elife 7: pii: e35677, 2018.

112. Ding Z, Wu CJ, Chu GC, Xiao Y, Ho D, Zhang J, Perry SR, Labrot ES, Wu X, Lis R, et al: SMAD4-dependent barrier constrains prostate cancer growth and metastatic progression. Nature 470: 269-273, 2011.

113. Zhang DT, Shi JG, Liu Y and Jiang HM: The prognostic value of Smad4 mRNA in patients with prostate cancer. Tumour Biol 35: 3333-3337, 2014

114. Guo J, Wang M, Wang Z and Liu X: Overexpression of pleomorphic adenoma gene-like 2 is a novel poor prognostic marker of prostate cancer. PLoS One 11: e0158667, 2016.

115. Li N, Li D, Du Y, Su C, Yang C, Lin C, Li X and Hu G: Overexpressed PLAGL2 transcriptionally activates Wnt6 and promotes cancer development in colorectal cancer. Oncol Rep 41: 875-884, 2019.

116. Zheng H, Ying H, Wiedemeyer R, Yan H, Quayle SN, Ivanova EV, Paik JH, Zhang H, Xiao Y, Perry SR, et al: PLAGL2 regulates Wnt signaling to impede differentiation in neural stem cells and gliomas. Cancer Cell 17: 497-509, 2010.

117. Landrette SF, Kuo YH, Hensen K, Barjesteh van Waalwijk va n Doorn-Khosrovani S, Perrat PN, Van de Ven WJ, Delwel R and Castilla LH: Plag1 and Plagl2 are oncogenes that induce acute myeloid leukemia in cooperation with Cbfb-MYH11. Blood 105: 2900-2907, 2005

118. Landrette SF, Madera D, He F and Castilla LH: The transcription factor PlagL2 activates Mpl transcription and signaling in hematopoietic progenitor and leukemia cells. Leukemia 25: 655-662, 2011.

119. Zhao SG, Lehrer J, Chang SL, Das R, Erho N, Liu Y, Sjöström M, Den RB, Freedland SJ, Klein EA, et al: The immune landscape of prostate cancer and nomination of PD-L2 as a potential therapeutic target. J Natl Cancer Inst 111: 301-310, 2019.

120. Kladi-Skandali A, Mavridis K, Scorilas A and Sideris DC: Expressional profiling and clinical relevance of RNase kappa in prostate cancer: A novel indicator of favorable progression-free survival. J Cancer Res Clin Oncol 144: 2049-2057, 2018.

121. Gkratsou AS, Fragoulis EG and Sideris DC: Effect of cytostatic drugs on the mRNA expression levels of ribonuclease $\kappa$ in breast and ovarian cancer cells. Anticancer Agents Med Chem 14: 400-408, 2014.

122. Ma X, Du T, Zhu D, Chen X, Lai Y, Wu W, Wang Q, Lin C, Li Z, Liu L and Huang H: High levels of glioma tumor suppressor candidate region gene 1 predicts a poor prognosis for prostate cancer. Oncol Lett 16: 6749-6755, 2018

123. Yang P, Kollmeyer TM, Buckner K, Bamlet W, Ballman KV and Jenkins RB: Polymorphisms in GLTSCR 1 and ERCC2 are associated with the development of oligodendrogliomas. Cancer 103: 2363-2372, 2005.

124. Alpsoy A and Dykhuizen EC: Glioma tumor suppressor candidate region gene 1 (GLTSCR1) and its paralog GLTSCR1-like form SWI/SNF chromatin remodeling subcomplexes. J Biol Chem 293: 3892-3903, 2018.

125. Gu Y, Chow MJ, Kapoor A, Mei W, Jiang Y, Yan J, De Melo J, Seliman M, Yang H, Cutz JC, et al: Biphasic alteration of butyrylcholinesterase (BChE) during prostate cancer development. Transl Oncol 11: 1012-1022, 2018.

126. Chatonnet A and Lockridge O: Comparison of butyrylcholinesterase and acetylcholinesterase. Biochem J 260: 625-634, 1989.

127. Evans FT, Gray PW, Lehmann H and Silk E: Sensitivity to succinylcholine in relation to serum-cholinesterase. Lancet 1: 1229-1230, 1952.

128. De Vriese C, Gregoire F, Lema-Kisoka R, Waelbroeck M, Robberecht P and Delporte C: Ghrelin degradation by serum and tissue homogenates: Identification of the cleavage sites. Endocrinology 145: 4997-5005, 2004.

129. Brimijoin S, Gao Y, Geng L and Chen VP: Treating cocaine addiction, obesity, and emotional disorders by viral gene transfer of butyrylcholinesterase. Front Pharmacol 9: 112, 2018.

130. Schopfer LM, Lockridge O and Brimijoin S: Pure human butyrylcholinesterase hydrolyzes octanoyl ghrelin to desacyl ghrelin. Gen Comp Endocrinol 224: 61-68, 2015

131. Brimijoin S, Chen VP, Pang YP, Geng L and Gao Y: Physiological roles for butyrylcholinesterase: A BChE-ghrelin axis. Chem Biol Interact 259: 271-275, 2016 
132. Erho N, Crisan A, Vergara IA, Mitra AP, Ghadessi M, Buerki C, Bergstralh EJ, Kollmeyer T, Fink S, Haddad Z, et al: Discovery and validation of a prostate cancer genomic classifier that predicts early metastasis following radical prostatectomy. PLoS One 8: e66855, 2013.

133. Karnes RJ, Bergstralh EJ, Davicioni E, Ghadessi M, Buerki C, Mitra AP, Crisan A, Erho N, Vergara IA, Lam LL, et al: Validation of a genomic classifier that predicts metastasis following radical prostatectomy in an at risk patient population. J Urol 190: 2047-2053, 2013.

134. Klein EA, Haddad Z, Yousefi K, Lam LL, Wang Q, Choeurng V, Palmer-Aronsten B, Buerki C, Davicioni E, Li J, et al: Decipher genomic classifier measured on prostate biopsy predicts metastasis risk. Urology 90: 148-152, 2016.

135. Knezevic D, Goddard AD, Natraj N, Cherbavaz DB, Clark-Langone KM, Snable J, Watson D, Falzarano SM, Magi-Galluzzi C, Klein EA and Quale C: Analytical validation of the Oncotype DX prostate cancer assay-a clinical RT-PCR assay optimized for prostate needle biopsies. BMC Genomics 14: 690, 2013.

136. Klein EA, Cooperberg MR, Magi-Galluzzi C, Simko JP, Falzarano SM, Maddala T, Chan JM, Li J, Cowan JE, Tsiatis AC, et al: A 17-gene assay to predict prostate cancer aggressiveness in the context of Gleason grade heterogeneity, tumor multifocality, and biopsy undersampling. Eur Urol 66: $550-560,2014$.

137. Cuzick J, Swanson GP, Fisher G, Brothman AR, Berney DM, Reid JE, Mesher D, Speights VO, Stankiewicz E, Foster CS, et al: Prognostic value of an RNA expression signature derived from cell cycle proliferation genes in patients with prostate cancer: A retrospective study. Lancet Oncol 12: 245-255, 2011.

138. Oderda M, Cozzi G, Daniele L, Sapino A, Munegato S, Renne G, De Cobelli O and Gontero P: Cell-cycle Progression-score might improve the current risk assessment in newly diagnosed prostate cancer patients. Urology 102: 73-78, 2017.

139. Albala D, Kemeter MJ, Febbo PG, Lu R, John V, Stoy D, Denes B, McCall M, Shindel AW and Dubeck F: Health economic impact and prospective clinical utility of oncotype DX® genomic prostate score. Rev Urol 18: 123-132, 2016

140. Cullen J, Rosner IL, Brand TC, Zhang N, Tsiatis AC, Moncur J Ali A, Chen Y, Knezevic D, Maddala T, et al: A Biopsy-based 17-gene genomic prostate score predicts recurrence after radical prostatectomy and adverse surgical pathology in a racially diverse population of men with clinically low- and intermediate-risk prostate cancer. Eur Urol 68: 123-131, 2015.

141. Cooperberg MR, Simko JP, Cowan JE, Reid JE, Djalilvand A, Bhatnagar S, Gutin A, Lanchbury JS, Swanson GP, Stone S and Carroll PR: Validation of a cell-cycle progression gene panel to improve risk stratification in a contemporary prostatectomy cohort. J Clin Oncol 31: 1428-1434, 2013.

142. Van Den Eeden SK, Lu R, Zhang N, Quesenberry CP Jr, Shan J, Han JS, Tsiatis AC, Leimpeter AD, Lawrence HJ, Febbo PG and Presti JC: A Biopsy-based 17-gene genomic prostate score as a predictor of metastases and prostate cancer death in surgically treated men with clinically localized disease. Eur Urol 73 129-138, 2018.

143. Eggener S, Karsh LI, Richardson T, Shindel AW, Lu R, Rosenberg S, Goldfischer E, Korman H, Bennett J, Newmark J and Denes BS: A 17-gene panel for prediction of adverse prostate cancer pathologic features: Prospective clinical validation and utility. Urology 126: 76-82, 2019.

144. Mosley JD and Keri RA: Cell cycle correlated genes dictate the prognostic power of breast cancer gene lists. BMC Med Genomics 1: 11, 2008.

145. Freedland SJ, Gerber L, Reid J, Welbourn W, Tikishvili E, Park J, Younus A, Gutin A, Sangale Z, Lanchbury JS, et al: Prognostic utility of cell cycle progression score in men with prostate cancer after primary external beam radiation therapy. Int J Radiat Oncol Biol Phys 86: 848-853, 2013.

146. Bishoff JT, Freedland SJ, Gerber L, Tennstedt P, Reid J, Welbourn W, Graefen M, Sangale Z, Tikishvili E, Park J, et al: Prognostic utility of the cell cycle progression score generated from biopsy in men treated with prostatectomy. J Urol 192 409-414, 2014.

147. Tosoian JJ, Chappidi MR, Bishoff JT, Freedland SJ, Reid J, Brawer M, Stone S, Schlomm T and Ross AE: Prognostic utility of biopsy-derived cell cycle progression score in patients with National Comprehensive Cancer Network low-risk prostate cancer undergoing radical prostatectomy: Implications for treatment guidance. BJU Int 120: 808-814, 2017.
148. Cuzick J, Berney DM, Fisher G, Mesher D, Møller H, Reid JE, Perry M, Park J, Younus A, Gutin A, et al: Prognostic value of a cell cycle progression signature for prostate cancer death in a conservatively managed needle biopsy cohort. Br J Cancer 106: 1095-1099, 2012.

149. Health Quality Ontario: Prolaris cell cycle progression test for localized prostate cancer: A health technology assessment. Ont Health Technol Assess Ser 17: 1-75, 2017.

150. Li F, Ji JP, Xu Y and Liu RL: Identification a novel set of 6 differential expressed genes in prostate cancer that can potentially predict biochemical recurrence after curative surgery. Clin Transl Oncol 21: 1067-1075, 2019.

151. Chu J, Li N and Gai W: Identification of genes that predict the biochemical recurrence of prostate cancer. Oncol Lett 16: 3447-3452, 2018.

152. Abou-Ouf H, Alshalalfa M, Takhar M, Erho N, Donnelly B, Davicioni E, Karnes RJ and Bismar TA: Validation of a 10-gene molecular signature for predicting biochemical recurrence and clinical metastasis in localized prostate cancer. J Cancer Res Clin Oncol 144: 883-891, 2018.

153. Russo MA, Ravenna L, Pellegrini L, Petrangeli E, Salvatori L, Magrone T, Fini M and Tafani M: Hypoxia and inflammation in prostate cancer progression. Cross-talk with androgen and estrogen receptors and cancer stem cells. Endocr Metab Immune Disord Drug Targets 16: 235-248, 2016.

154. Marignol L, Rivera-Figueroa K, Lynch T and Hollywood D: Hypoxia, notch signalling, and prostate cancer. Nat Rev Urol 10: 405-413, 2013.

155. Yang L, Roberts D, Takhar M, Erho N, Bibby BAS, Thiruthaneeswaran N, Bhandari V, Cheng WC, Haider S, McCorry AMB, et al: Development and validation of a 28-gene Hypoxia-related prognostic signature for localized prostate cancer. EBioMedicine 31: 182-189, 2018.

156. Jiang Y, Mei W, Gu Y, Lin X, He L, Zeng H, Wei F, Wan X, Yang H, Major P and Tang D: Construction of a set of novel and robust gene expression signatures predicting prostate cancer recurrence. Mol Oncol 12: 1559-1578, 2018.

157. Apostolopoulos V, Stojanovska L and Gargosky SE: MUC1 (CD227): A multi-tasked molecule. Cell Mol Life Sci 72: 4475-4500, 2015.

158. Kufe DW: Mucins in cancer: Function, prognosis and therapy. Nat Rev Cancer 9: 874-885, 2009.

159. Nath S and Mukherjee P: MUC1: A multifaceted oncoprotein with a key role in cancer progression. Trends Mol Med 20: 332-342, 2014

160. Wurz GT, Kao CJ, Wolf M and DeGregorio MW: Tecemotide: An antigen-specific cancer immunotherapy. Hum Vaccin Immunother 10: 3383-3393, 2014.

161. Eminaga O, Wei W, Hawley SJ, Auman H, Newcomb LF, Simko J, Hurtado-Coll A, Troyer DA, Carroll PR, Carroll PR, et al: MUC1 expression by immunohistochemistry is associated with adverse pathologic features in prostate cancer: A Multi-institutional Study. PLoS One 11: e0165236, 2016

162. Wong N, Major P, Kapoor A, Wei F, Yan J, Aziz T, Zheng M, Jayasekera D, Cutz JC, Chow MJ and Tang D: Amplification of MUC1 in prostate cancer metastasis and CRPC development. Oncotarget 7: 83115-83133, 2016.

163. Lin X, Gu Y, Kapoor A, Wei F, Aziz T, Ojo D, Jiang Y, Bonert M, Shayegan B, Yang H, et al: Overexpression of MUC1 and genomic alterations in its network associate with prostate cancer progression. Neoplasia 19: 857-867, 2017

164. Tarnowski M, Czerewaty M, Deskur A, Safranow K, Marlicz W, Urasińska E, Ratajczak MZ and Starzyńska T: Expression of cancer testis antigens in colorectal cancer: New prognostic and therapeutic implications. Dis Markers 2016: 1987505, 2016.

165. Stellfox ME, Nardi IK, Knippler CM and Foltz DR: Differential binding partners of the Mis18a/ $\beta$ YIPPEE domains regulate Mis18 complex recruitment to centromeres. Cell Rep 15: 2127-2135, 2016

166. Nardi IK, Zasadzińska E, Stellfox ME, Knippler CM and Foltz DR: Licensing of centromeric chromatin assembly through the Mis18a-Mis18 $\beta$ heterotetramer. Mol Cell 61: 774-787, 2016.

167. Wang D, Chen Z, Lin F, Wang Z, Gao Q, Xie H, Xiao H, Zhou Y, Zhang F, Ma Y, et al: OIP5 promotes growth, metastasis and chemoresistance to cisplatin in bladder cancer cells. J Cancer 9: 4684-4695, 2018

168. He J, Zhao Y, Zhao E, Wang X, Dong Z, Chen Y, Yang L and Cui H: Cancer-testis specific gene OIP5: A downstream gene of $\mathrm{E} 2 \mathrm{~F} 1$ that promotes tumorigenesis and metastasis in glioblastoma by stabilizing E2F1 signaling. Neuro Oncol 20: 1173-1184, 2018. 
169. Gong M, Xu Y, Dong W, Guo G, Ni W, Wang Y, Wang Y and An R: Expression of Opa interacting protein 5 (OIP5) is associated with tumor stage and prognosis of clear cell renal cell carcinoma. Acta Histochem 115: 810-815, 2013.

170. Chun HK, Chung KS, Kim HC, Kang JE, Kang MA, Kim JT, Choi EH, Jung KE, Kim MH, Song EY, et al: OIP5 is a highly expressed potential therapeutic target for colorectal and gastric cancers. BMB Rep 43: 349-354, 2010.

171. Mobasheri MB, Shirkoohi R and Modarressi MH: Cancer/Testis OIP5 and TAF7L Genes are Up-regulated in breast cancer. Asian Pac J Cancer Prev 16: 4623-4628, 2015.

172. López-Urrutia E, Bustamante Montes LP, Ladrón de Guevara Cervantes D, Pèrez-Plasencia C and Campos-Parra AD: Crosstalk between long Non-coding RNAs, Micro-RNAs and mRNAs: Deciphering molecular mechanisms of master regulators in cancer. Front Oncol 9: 669, 2019.

173. Salmena L, Poliseno L, Tay Y, Kats L and Pandolfi PP: A ceRNA hypothesis: The Rosetta stone of a hidden RNA language? Cell 146: 353-358, 2011.

174. Ramnarine VR, Kobelev M, Gibb EA, Nouri M, Lin D, Wang Y, Buttyan R, Davicioni E, Zoubeidi A and Collins CC: The evolution of long noncoding RNA acceptance in prostate cancer initiation and progression, and its clinical utility in disease management. Eur Urol: Aug 22, 2019 (Epub ahead of print).

175. Bussemakers MJ, van Bokhoven A, Verhaegh GW, Smit FP, Karthaus HF, Schalken JA, Debruyne FM, Ru N and Isaacs WB: DD3: A new prostate-specific gene, highly overexpressed in prostate cancer. Cancer Res 59: 5975-5979, 1999.

176. Crawford ED, Rove KO, Trabulsi EJ, Qian J, Drewnowska KP, Kaminetsky JC, Huisman TK, Bilowus ML, Freedman SJ, Glover WL Jr and Bostwick DG: Diagnostic performance of PCA3 to detect prostate cancer in men with increased prostate specific antigen: A prospective study of 1,962 cases. J Urol 188: $1726-1731,2012$.

177. Deras IL, Aubin SM, Blase A, Day JR, Koo S, Partin AW, Ellis WJ, Marks LS, Fradet Y, Rittenhouse H and Groskopf J: PCA3: A molecular urine assay for predicting prostate biopsy outcome. J Urol 179: 1587-1592, 2008

178. Gittelman MC, Hertzman B, Bailen J, Williams T, Koziol I, Henderson RJ, Efros M, Bidair M and Ward JF: PCA3 molecular urine test as a predictor of repeat prostate biopsy outcome in men with previous negative biopsies: A prospecAive multicenter clinical study. J Urol 190: 64-69, 2013.

179. Ma W, Chen X, Ding L, Ma J, Jing W, Lan T, Sattar H, Wei Y, Zhou $\mathrm{F}$ and Yuan Y: The prognostic value of long noncoding RNAs in prostate cancer: A systematic review and meta-analysis. Oncotarget 8: 57755-57765, 2017.

180. Wu XL, Zhang JW, Li BS, Peng SS and Yuan YQ: The prognostic value of abnormally expressed lncRNAs in prostatic carcinoma: A systematic review and meta-analysis. Medicine (Baltimore) 96: e9279, 2017.

181. Wang J, Cheng G, Li X, Pan Y, Qin C, Yang H, Hua L and Wang Z: Overexpression of long non-coding RNA LOC400891 promotes tumor progression and poor prognosis in prostate cancer. Tumour Biol 37: 9603-9613, 2016.

182. Xu S, Yi XM, Tang CP, Ge JP, Zhang ZY and Zhou WQ: Long non-coding RNA ATB promotes growth and epithelial-mesenchymal transition and predicts poor prognosis in human prostate carcinoma. Oncol Rep 36: 10-22, 2016

183. Yuan JH, Yang F, Wang F, Ma JZ, Guo YJ, Tao QF, Liu F, Pan W, Wang TT, Zhou CC, et al: A long noncoding RNA activated by TGF- $\beta$ promotes the invasion-metastasis cascade in hepatocellular carcinoma. Cancer Cell 25: 666-681, 2014.

184. Xiao H, Zhang F, Zou Y, Li J, Liu Y and Huang W: The function and mechanism of long Non-coding RNA-ATB in cancers. Front Physiol 9: 321, 2018.

185. Wu J, Cheng G, Zhang C, Zheng Y, Xu H, Yang $\mathrm{H}$ and Hua L: Long noncoding RNA LINC01296 is associated with poor prognosis in prostate cancer and promotes cancer-cell proliferation and metastasis. Onco Targets Ther 10 : 1843-1852, 2017.

186. Qiu JJ and Yan JB: Long non-coding RNA LINC01296 is a potential prognostic biomarker in patients with colorectal cancer. Tumour Biol 36: 7175-7183, 2015.

187. Seitz AK, Christensen LL, Christensen E, Faarkrog K, Ostenfeld MS, Hedegaard J, Nordentoft I, Nielsen MM, Palmfeldt $\mathrm{J}$, Thomson $\mathrm{M}$, et al: Profiling of long non-coding RNAs identifies LINC00958 and LINC01296 as candidate oncogenes in bladder cancer. Sci Rep 7: 395, 2017.
188. Wang K, Zhang M, Wang C and Ning X: Long Noncoding RNA LINC01296 Harbors miR-21a to regulate colon carcinoma proliferation and invasion. Oncol Res 27: 541-549, 2019.

189. Qin QH, Yin ZQ, Li Y, Wang BG and Zhang MF: Long intergenic noncoding RNA 01296 aggravates gastric cancer cells progress through miR-122/MMP-9. Biomed Pharmacother 97: 450-457, 2018.

190. Zhang D, Li H, Xie J, Jiang D, Cao L, Yang X, Xue P and Jiang X: Long noncoding RNA LINC01296 promotes tumor growth and progression by sponging miR-5095 in human cholangiocarcinoma. Int J Oncol 52: 1777-1786, 2018.

191. Jiang M, Xiao Y, Liu D, Luo N, Gao Q and Guan Y: Overexpression of long noncoding RNA LINC01296 indicates an unfavorable prognosis and promotes tumorigenesis in breast cancer. Gene 675: 217-224, 2018.

192. Hu X, Duan L, Liu H and Zhang L: Long noncoding RNA LINC01296 induces non-small cell lung cancer growth and progression through sponging miR-5095. Am J Transl Res 11: 895-903, 2019

193. Feng W, Zhai C, Shi W, Zhang Q, Yan X, Wang J, Wang Q and Li M: Clinicopathological and prognostic value of LINC01296 in cancers: A meta-analysis. Artif Cells Nanomed Biotechnol 47: $3315-3321,2019$

194. Wan Y, Li M and Huang P: LINC01296 promotes proliferation, migration, and invasion of HCC cells by targeting miR-122-5P and modulating EMT activity. Onco Targets Ther 12: 2193-2203, 2019.

195. Prensner JR, Iyer MK, Sahu A, Asangani IA, Cao Q, Patel L, Vergara IA, Davicioni E, Erho N, Ghadessi M, et al: The long noncoding RNA SChLAP1 promotes aggressive prostate cancer and antagonizes the SWI/SNF complex. Nat Genet 45: 1392-1398, 2013.

196. Mehra R, Udager AM, Ahearn TU, Cao X, Feng FY, Loda M, Petimar JS, Kantoff P, Mucci LA and Chinnaiyan AM: Overexpression of the long Non-coding RNA SChLAP1 independently predicts lethal prostate cancer. Eur Urol 70: 549-552, 2016.

197. Prensner JR, Zhao S, Erho N, Schipper M, Iyer MK, Dhanasekaran SM, Magi-Galluzzi C, Mehra R, Sahu A, Siddiqui J, et al: RNA biomarkers associated with metastatic progression in prostate cancer: A multi-institutional high-throughput analysis of SChLAP1. Lancet Oncol 15: 1469-1480, 2014.

198. Mehra R, Shi Y, Udager AM, Prensner JR, Sahu A, Iyer MK, Siddiqui J, Cao X, Wei J, Jiang H, et al: A novel RNA in situ hybridization assay for the long noncoding RNA SChLAP1 predicts poor clinical outcome after radical prostatectomy in clinically localized prostate cancer. Neoplasia 16: 1121-1127, 2014.

199. Raab JR, Smith KN, Spear CC, Manner CJ, Calabrese JM and Magnuson T: SWI/SNF remains localized to chromatin in the presence of SCHLAP1. Nat Genet 51: 26-29, 2019.

200. Fotouhi Ghiam A, Taeb S, Huang X, Huang V, Ray J, Scarcello S, Hoey C, Jahangiri S, Fokas E, Loblaw A, et al: Long non-coding RNA urothelial carcinoma associated 1 (UCA1) mediates radiation response in prostate cancer. Oncotarget 8: 4668-4689, 2017.

201. Na XY, Liu ZY, Ren PP, Yu R and Shang XS: Long non-coding RNA UCA1 contributes to the progression of prostate cancer and regulates proliferation through KLF4-KRT6/13 signaling pathway. Int J Clin Exp Med 8: 12609-12616, 2015.

202. Wang F, Zhou J, Xie X, Hu J, Chen L, Hu Q, Guo H and Yu C: Involvement of SRPK1 in cisplatin resistance related to long non-coding RNA UCA1 in human ovarian cancer cells. Neoplasma 62: 432-438, 2015.

203. Zheng Q, Wu F, Dai WY, Zheng DC, Zheng C, Ye H, Zhou B, Chen JJ and Chen P: Aberrant expression of UCA1 in gastric cancer and its clinical significance. Clin Transl Oncol 17: 640-646, 2015.

204. Tian Y, Zhang X, Hao Y, Fang Z and He Y: Potential roles of abnormally expressed long noncoding RNA UCA1 and Malat-1 in metastasis of melanoma. Melanoma Res 24: 335-341, 2014.

205. Chen P, Wan D, Zheng D, Zheng Q, Wu F and Zhi Q: Long non-coding RNA UCA1 promotes the tumorigenesis in pancreatic cancer. Biomed Pharmacother 83: 1220-1226, 2016.

206.Zhao W, Sun C and Cui Z: A long noncoding RNA UCA1 promotes proliferation and predicts poor prognosis in glioma. Clin Transl Oncol 19: 735-741, 2017.

207. Xuan W, Yu H, Zhang X and Song D: Crosstalk between the lncRNA UCA1 and microRNAs in cancer. FEBS Lett 593: 1901-1914, 2019 
208.Zhang S, Dong X, Ji T, Chen G and Shan L: Long non-coding RNA UCA1 promotes cell progression by acting as a competing endogenous RNA of ATF2 in prostate cancer. Am J Trans Res 9: 366-375, 2017

209. He C, Lu X, Yang F, Qin L, Guo Z, Sun Y and Wu J: LncRNA UCA1 acts as a sponge of miR-204 to up-regulate CXCR4 expression and promote prostate cancer progression. Biosci Rep 39: pii: BSR20181465, 2019.

210. Shukla S, Zhang X, Niknafs YS, Xiao L, Mehra R, Cieślik M, Ross A, Schaeffer E, Malik B, Guo S, et al: Identification and validation of PCAT14 as prognostic biomarker in prostate cancer. Neoplasia 18: 489-499, 2016.

211. White NM, Zhao SG, Zhang J, Rozycki EB, Dang HX, McFadden SD, Eteleeb AM, Alshalalfa M, Vergara IA, Erho N, et al: Multi-institutional analysis shows that low PCAT-14 expression associates with poor outcomes in prostate cancer. Eur Urol 71: 257-266, 2017.

212. Wang Y, Hu Y, Wu G, Yang Y, Tang Y, Zhang W, Wang K, Liu Y, Wang $X$ and $\mathrm{Li}$ T: Long noncoding RNA PCAT-14 induces proliferation and invasion by hepatocellular carcinoma cells by inducing methylation of miR-372. Oncotarget 8: 34429-34441, 2017.

213. Huang TB, Dong CP, Zhou GC, Lu SM, Luan Y, Gu X, Liu L and Ding XF: A potential panel of four-long noncoding RNA signature in prostate cancer predicts biochemical recurrence-free survival and disease-free survival. Int Urol Nephrol 49: 825-835, 2017.

214. Shao N, Tang H, Qu Y, Wan F and Ye D: Development and validation of lncRNAs-based nomogram for prediction of biochemical recurrence in prostate cancer by bioinformatics analysis. J Cancer 10: 2927-2934, 2019.

215. Shao N, Zhu Y, Wan FN and Ye DW: Identification of seven long noncoding RNAs signature for prediction of biochemical recurrence in prostate cancer. Asian J Androl: Mar 5, 2019 (Epub ahead of print).

216. Xu J, Lan Y, Yu F, Zhu S, Ran J, Zhu J, Zhang H, Li L, Cheng S, $\mathrm{Xiao} Y$ and Li X: Transcriptome analysis reveals a long non-coding RNA signature to improve biochemical recurrence prediction in prostate cancer. Oncotarget 9: 24936-24949, 2018.

217. Diao P, Song Y, Ge H, Wu Y, Li J, Zhang W, Wang Y and Cheng J: Identification of 4-lncRNA prognostic signature in head and neck squamous cell carcinoma. J Cell Biochem 120 10010-10020, 2019

218. Zhang J, Yin M, Peng G and Zhao Y: CRNDE: An important oncogenic long non-coding RNA in human cancers. Cell Prolif 51: e12440, 2018.

219. Li J, Zhang Z, Xiong L, Guo C, Jiang T, Zeng L, Li G and Wang J: SNHG1 lncRNA negatively regulates miR-199a-3p to enhance CDK7 expression and promote cell proliferation in prostate cancer. Biochem Biophys Res Commun 487: 146-152, 2017.

220. Thin KZ, Tu JC and Raveendran S: Long non-coding SNHG1 in cancer. Clin Chim Acta 494: 38-47, 2019.

221. Sun M, Geng D, Li S, Chen Z and Zhao W: LncRNA PART1 modulates toll-like receptor pathways to influence cell proliferation and apoptosis in prostate cancer cells. Biol Chem 399 387-395, 2018

222.Zhu D, Yu Y, Wang W, Wu K, Liu D, Yang Y, Zhang C, Qi Y and Zhao S: Long noncoding RNA PART1 promotes progression of non-small cell lung cancer cells via JAK-STAT signaling pathway. Cancer Med: Aug 22, 2019 (Epub ahead of print).

223. Hu X, Feng H, Huang H, Gu W, Fang Q, Xie Y, Qin C and Hu X: Downregulated long noncoding RNA PART1 inhibits proliferation and promotes apoptosis in bladder cancer. Technol Cancer Res Treat 18: 1533033819846638, 2019.

224.Zhihua Z, Weiwei W, Lihua N, Jianying Z and Jiang G: p53-induced long non-coding RNA PGM5-AS1 inhibits the progression of esophageal squamous cell carcinoma through regulating miR-466/PTEN axis. IUBMB Life 71: 1492-1502, 2019

225. Liu Q, Wu Y, Xiao J and Zou J: Long Non-coding RNA prostate cancer-associated Transcript 7 (PCAT7) induces poor prognosis and promotes tumorigenesis by inhibiting mir-134-5p in Non-small-cell lung (NSCLC). Med Sci Monit 23: 6089-6098, 2017.

226. Yuan Q, Chu H, Ge Y, Ma G, Du M, Wang M, Zhang Z and Zhang W: LncRNA PCAT1 and its genetic variant rs1902432 are associated with prostate cancer risk. J Cancer 9: 1414-1420, 2018 .
227. Shang Z, Yu J, Sun L, Tian J, Zhu S, Zhang B, Dong Q, Jiang N, Flores-Morales A, Chang C and Niu Y: LncRNA PCAT1 activates $\mathrm{AKT}$ and NF-kappaB signaling in castration-resistant prostate cancer by regulating the PHLPP/FKBP51/IKKa complex. Nucleic Acids Res 47: 4211-4225, 2019.

228. Han Y, Rand KA, Hazelett DJ, Ingles SA, Kittles RA, Strom SS, Rybicki BA, Nemesure B, Isaacs WB, Stanford JL, et al: Prostate cancer susceptibility in men of african ancestry at 8q24. J Natl Cancer Inst: 108, 2016 doi: 10.1093/jnci/djv431.

229. Huang L, Wang Y, Chen J, Wang Y, Zhao Y, Wang Y, Ma Y, Chen X, Liu W, Li Z, et al: Long noncoding RNA PCAT1, a novel serum-based biomarker, enhances cell growth by sponging miR-326 in oesophageal squamous cell carcinoma. Cell Death Dis 10: 513, 2019.

230. Yang ML, Huang Z, Wu LN, Wu R, Ding HX and Wang BG lncRNA-PCAT1 rs2632159 polymorphism could be a biomarker for colorectal cancer susceptibility. Biosci Rep 39: pii BSR20190708, 2019

231. Zhao X, Fan Y, Lu C, Li H, Zhou N, Sun G and Fan H: PCAT1 is a poor prognostic factor in endometrial carcinoma and associated with cancer cell proliferation, migration and invasion. Bosn J Basic Med Sci 19: 274-281, 2019.

232. Bartolomei MS, Zemel S and Tilghman SM: Parental imprinting of the mouse H19 gene. Nature 351: 153-155, 1991.

233. Brockdorff N, Ashworth A, Kay GF, McCabe VM, Norris DP, Cooper PJ, Swift S and Rastan S: The product of the mouse Xist gene is a $15 \mathrm{~kb}$ inactive $\mathrm{X}$-specific transcript containing no conserved ORF and located in the nucleus. Cell 71: 515-526, 1992.

234. Ward JF and Moul JW: Biochemical recurrence after definitive prostate cancer therapy. Part I: Defining and localizing biochemical recurrence of prostate cancer. Curr Opin Urol 15: $181-186,2005$

235. Ward JF and Moul JW: Biochemical recurrence after definitive prostate cancer therapy. Part II: Treatment strategies for biochemical recurrence of prostate cancer. Curr Opin Urol 15 $187-195,2005$

236. McCormick BZ, Mahmoud AM, Williams SB and Davis JW: Biochemical recurrence after radical prostatectomy: Current status of its use as a treatment endpoint and early management strategies. Indian J Urol 35: 6-17, 2019

237. Spratt DE, McHugh DJ, Morris MJ and Morgans AK: Management of biochemically recurrent prostate cancer: Ensuring the right treatment of the right patient at the right time. Am Soc Clin Oncol Educ Book 38: 355-362, 2018.

238. Gillessen S, Attard G, Beer TM, Beltran H, Bossi A, Bristow R, Carver B, Castellano D, Chung BH, Clarke N, et al: Management of patients with advanced prostate cancer: The report of the advanced prostate cancer consensus conference APCCC 2017. Eur Urol 73: 178-211, 2018

239. Rahbar K, Afshar-Oromieh A, Jadvar H and Ahmadzadehfar $\mathrm{H}$ PSMA theranostics: Current status and future directions. Mol Imaging 17: 1536012118776068, 2018.

240. Wester HJ and Schottelius M: PSMA-Targeted radiopharmaceuticals for imaging and therapy. Semin Nucl Med 49: 302-312, 2019.

241. O'Keefe DS, Bacich DJ, Huang SS and Heston WDW: A perspective on the evolving story of PSMA biology, PSMA-based imaging, and endoradiotherapeutic strategies. J Nucl Med 59: 1007-1013, 2018

242. Israeli RS, Powell CT, Corr JG, Fair WR and Heston WD: Expression of the prostate-specific membrane antigen. Cancer Res 54: 1807-1811, 1994

243. Sweat SD, Pacelli A, Murphy GP and Bostwick DG: Prostate-specific membrane antigen expression is greatest in prostate adenocarcinoma and lymph node metastases. Urology 52: 637-640, 1998.

244. Wright GL Jr, Grob BM, Haley C, Grossman K, Newhall K Petrylak D, Troyer J, Konchuba A, Schellhammer PF and Moriarty R: Upregulation of prostate-specific membrane antigen after androgen-deprivation therapy. Urology 48: 326-334, 1996.

245. Marchal C, Redondo M, Padilla M, Caballero J, Rodrigo I, García J, Quian J and Boswick DG: Expression of prostate specific membrane antigen (PSMA) in prostatic adenocarcinoma and prostatic intraepithelial neoplasia. Histol Histopathol 19 : 715-718, 2004

246. Sheikhbahaei S, Werner RA, Solnes LB, Pienta KJ, Pomper MG, Gorin MA and Rowe SP: Prostate-specific membrane antigen (PSMA)-targeted PET imaging of prostate cancer: An update on important pitfalls. Semin Nucl Med 49: 255-270, 2019. 
247. Bouchelouche $\mathrm{K}$ and Sathekge MM: Letter from the editors. Semin Nucl Med 49: 245-246, 2019.

248. Fendler WP, Calais J, Eiber M, Flavell RR, Mishoe A, Feng FY, Nguyen HG, Reiter RE, Rettig MB, Okamoto S, et al: Assessment of $68 \mathrm{Ga}-\mathrm{PSMA}-11$ PET accuracy in localizing recurrent prostate cancer: A prospective Single-Arm clinical trial. JAMA Oncol 5: 856-863, 2019.

249. Rahbar K, Afshar-Oromieh A, Seifert R, Wagner S, Schäfers M, Bögemann $\mathrm{M}$ and Weckesser M: Diagnostic performance of ${ }^{18}$ F-PSMA-1007 PET/CT in patients with biochemical recurrent prostate cancer. Eur J Nucl Med Mol Imaging 45: 2055-2061, 2018

250. Karnes RJ, Choeurng V, Ross AE, Schaeffer EM, Klein EA, Freedland SJ, Erho N, Yousefi K, Takhar M, Davicioni E, et al: Validation of a genomic risk classifier to predict prostate cancer-specific mortality in men with adverse pathologic features. Eur Urol 73: 168-175, 2018.

251. Cooperberg MR, Davicioni E, Crisan A, Jenkins RB Ghadessi M and Karnes RJ: Combined value of validated clinical and genomic risk stratification tools for predicting prostate cancer mortality in a high-risk prostatectomy cohort. Eur Urol 67: 326-333, 2015

252. Wiegel T, Bartkowiak D, Bottke D, Bronner C, Steiner U, Siegmann A, Golz R, Störkel S, Willich N, Semjonow A, et al: Adjuvant radiotherapy versus wait-and-see after radical prostatectomy: 10-year follow-up of the ARO 96-02/AUO AP 09/95 trial. Eur Urol 66: 243-250, 2014.

253. Li H, Wang Z, Zhang Y, Sun G, Ding B, Yan L, Liu H, Guan W, $\mathrm{Hu} \mathrm{Z}$, Wang S, et al: The immune checkpoint regulator PDL1 is an independent prognostic biomarker for biochemical recurrence in prostate cancer patients following adjuvant hormonal therapy. J Cancer 10: 3102-3111, 2019.

254. Van den Broeck T, van den Bergh RCN, Briers E, Cornford P, Cumberbatch M, Tilki D, De Santis M, Fanti S, Fossati N, Gillessen S, et al: Biochemical recurrence in prostate cancer: The European association of urology prostate cancer guidelines panel recommendations. Eur Urol Focus: Jun 24, 2019 (Epub ahead of print).

255. Tendulkar RD, Agrawal S, Gao T, Efstathiou JA, Pisansky TM, Michalski JM, Koontz BF, Hamstra DA, Feng FY, Liauw SL, et al: Contemporary update of a Multi-institutional predictive nomogram for salvage radiotherapy after radical prostatectomy. J Clin Oncol 34: 3648-3654, 2016.

256. Isharwal S and Stephenson AJ: Post-prostatectomy radiation therapy for locally recurrent prostate cancer. Expert Rev Anticancer Ther 17: 1003-1012, 2017.

257. Tilki D, Preisser F, Graefen M, Huland H and Pompe RS External validation of the European association of urology biochemical recurrence risk groups to predict metastasis and mortality after radical prostatectomy in a european cohort. Eur Urol 75: 896-900, 2019.

258. Spratt DE, Dess RT, Zumsteg ZS, Lin DW, Tran PT, Morgan TM, Antonarakis ES, Nguyen PL, Ryan CJ, Sandler HM, et al: A systematic review and framework for the use of hormone therapy with salvage radiation therapy for recurrent prostate cancer. Eur Urol 73: 156-165, 2018.

259. Shipley WU, Seiferheld W, Lukka HR, Major PP, Heney NM, Grignon DJ, Sartor O, Patel MP, Bahary JP, Zietman AL, et al: Radiation with or without antiandrogen therapy in recurrent prostate cancer. N Engl J Med 376: 417-428, 2017

260. Freedland SJ, Choeurng V, Howard L, De Hoedt A, du Plessis M, Yousefi K, Lam LL, Buerki C, Ra S, Robbins B, et al: Utilization of a genomic classifier for prediction of metastasis following salvage radiation therapy after radical prostatectomy. Eur Urol 70: 588-596, 2016.

261. Semenas J, Allegrucci C, Boorjian SA, Mongan NP and Persson JL: Overcoming drug resistance and treating advanced prostate cancer. Curr Drug Targets 13: 1308-1323, 2012.

262. Cucchiara V, Cooperberg MR, Dall'Era M, Lin DW, Montorsi F, Schalken JA and Evans CP: Genomic markers in prostate cance decision making. Eur Urol 73: 572-582, 2018.

263. Pikor L, Thu K, Vucic E and Lam W: The detection and implication of genome instability in cancer. Cancer Metastasis Rev 32 341-352, 2013

264. Lin X, Ojo D, Wei F, Wong N, Gu Y and Tang D: A novel aspect of tumorigenesis-BMI1 functions in regulating DNA damage response. Biomolecules 5: 3396-3415, 2015.

265. Lin X, Yan J and Tang D: ERK kinases modulate the activation of PI3 kinase related kinases (PIKKs) in DNA damage response. Histol Histopathol 28: 1547-1554, 2013.
266. Wei F, Yan J and Tang D: Extracellular signal-regulated kinases modulate DNA damage response-a contributing factor to using MEK inhibitors in cancer therapy. Curr Med Chem 18: 5476-5482, 2011.

267. Lucarelli G, Loizzo D, Ferro M, Rutigliano M, Vartolomei MD, Cantiello F, Buonerba C, Di Lorenzo G, Terracciano D, De Cobelli O, et al: Metabolomic profiling for the identification of novel diagnostic markers and therapeutic targets in prostate cancer: An update. Expert Rev Mol Diagn 19: 377-387, 2019.

268. Williams D and Fingleton B: Non-canonical roles for metabolic enzymes and intermediates in malignant progression and metastasis. Clin Exp Metastasis 36: 211-224, 2019.

269. Priolo C, Pyne S, Rose J, Regan ER, Zadra G, Photopoulos C, Cacciatore S, Schultz D, Scaglia N, McDunn J, et al: AKT1 and MYC induce distinctive metabolic fingerprints in human prostate cancer. Cancer Res 74: 7198-7204, 2014.

270. Pettersson A, Gerke T, Penney KL, Lis RT, Stack EC, Pértega-Gomes N, Zadra G, Tyekucheva S, Giovannucci EL, Mucci LA and Loda M: MYC overexpression at the protein and mRNA level and cancer outcomes among men treated with radical prostatectomy for prostate cancer. Cancer Epidemiol Biomarkers Prev 27: 201-207, 2018.

271. Hammarsten P, Cipriano M, Josefsson A, Stattin P, Egevad L, Granfors T and Fowler CJ: Phospho-Akt immunoreactivity in prostate cancer: Relationship to disease severity and outcome, Ki67 and phosphorylated EGFR expression. PLoS One 7: e47994, 2012

272. Flegal KM, Kit BK, Orpana H and Graubard BI: Association of all-cause mortality with overweight and obesity using standard body mass index categories: A systematic review and meta-analysis. JAMA 309: 71-82, 2013

273. Schiffmann J, Karakiewicz PI, Rink M, Manka L, Salomon G, Tilki D, Budäus L, Pompe R, Leyh-Bannurah SR, Haese A, et al: Obesity paradox in prostate cancer: Increased body mass index was associated with decreased risk of metastases after surgery in 13,667 patients. World J Urol 36: 1067-1072, 2018.

274. Bansal D, Undela K, D'Cruz S and Schifano F: Statin use and risk of prostate cancer: A meta-analysis of observational studies. PLoS One 7: e46691, 2012

275. Kollmeier MA, Katz MS, Mak K, Yamada Y, Feder DJ, Zhang Z, Jia X, Shi W and Zelefsky MJ: Improved biochemical outcomes with statin use in patients with high-risk localized prostate cancer treated with radiotherapy. Int J Radiat Oncol Biol Phys 79: 713-718, 2011.

276. Song C, Park S, Park J, Shim M, Kim A, Jeong IG, Hong JH, Kim CS and Ahn H: Statin use after radical prostatectomy reduces biochemical recurrence in men with prostate cancer. Prostate 75: 211-217, 2015

277. Freedland SJ, Hamilton RJ, Gerber L, Banez LL, Moreira DM, Andriole GL and Rittmaster RS: Statin use and risk of prostate cancer and high-grade prostate cancer: Results from the REDUCE study. Prostate Cancer Prostatic Dis 16: 254-259, 2013.

278. Nordström T, Clements M, Karlsson R, Adolfsson J and Grönberg H: The risk of prostate cancer for men on aspirin, statin or antidiabetic medications. Eur J Cancer 51: 725-733, 2015.

279. Rieken M,Kluth LA, Xylinas E, Seitz C, Fajkovic H, KarakiewiczPI, Lotan Y, Briganti A, Loidl W, Faison T, et al: Impact of statin use on biochemical recurrence in patients treated with radical prostatectomy. Prostate Cancer Prostatic Dis 16: 367-371, 2013.

280. Pazhanisamy SK: Stem cells, DNA damage, ageing and cancer. Hematol Oncol Stem Cell Ther 2: 375-384, 2009.

281. Vitale I, Manic G, De Maria R, Kroemer G and Galluzzi L: DNA damage in stem cells. Mol Cell 66: 306-319, 2017.

282. Siddique HR and Saleem M: Role of BMI1, a stem cell factor, in cancer recurrence and chemoresistance: Preclinical and clinical evidences. Stem Cells 30: 372-378, 2012.

283. Lin X, Gu Y and Tang D: BMI1, ATM and DDR. Oncoscience 2: 665-666, 2015

284. Lin X, Wei F, Whyte P and Tang D: BMI1 reduces ATR activation and signalling caused by hydroxyurea. Oncotarget 8: 89707-89721, 2017.

285. Wei F, Ojo D, Lin X, Wong N, He L, Yan J, Xu S, Major P and Tang D: BMI1 attenuates etoposide-induced G2/M checkpoints via reducing ATM activation. Oncogene 34: 3063-3075, 2015.

286. Wei L, Wang J, Lampert E, Schlanger S, DePriest AD, Hu Q, Gomez EC, Murakam M, Glenn ST, Conroy J, et al: Intratumoral and intertumoral genomic heterogeneity of multifocal localized prostate cancer impacts molecular classifications and genomic prognosticators. Eur Urol 71: 183-192, 2017.

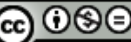

This work is licensed under a Creative Commons Attribution-NonCommercial-NoDerivatives 4.0 International (CC BY-NC-ND 4.0) License. 